\title{
Tectonics
}

\author{
RESEARCH ARTICLE \\ 10.1029/2020TC006153 \\ Key Points: \\ - The Aiguilles Rouges Massif \\ underwent transpression at $\sim 320 \mathrm{Ma}$ \\ similarly to Argentera Massif, \\ Maures Massif, and Corsica-Sardinia \\ Block \\ - Aiguilles Rouges Massif, Argentera \\ Massif, Maures Massif, and \\ Corsica-Sardinia Block were all part \\ of the East Variscan Shear Zone \\ - The East Variscan Shear Zone is a \\ long-lasting system of shear zones \\ that evolved following the "growth \\ by linkage" model
}

Supporting Information:

- Supporting Information S1

- Figure S1

- Table S1

- Figure S2

- Figure S3

- Table S2

Correspondence to:

M. Simonetti,

matteo.simonetti@unito.it

Citation:

Simonetti, M., Carosi, R., Montomoli, C., Cottle, J. M., \& Law, R. D. (2020). Transpressive deformation in the Southern European Variscan Belt: New insights from the Aiguilles Rouges Massif (Western Alps). Tectonics, 39 e2020TC006153. https://doi.org/ 10.1029/2020TC006153

Received 27 FEB 2020 Accepted 29 APR 2020 Accepted article online 4 MAY 2020

(C)2020. American Geophysical Union. All Rights Reserved.

\section{Transpressive Deformation in the Southern European Variscan Belt: New Insights From the Aiguilles Rouges Massif (Western Alps)}

\author{
M. Simonetti ${ }^{1}$ (D), R. $\operatorname{Carosi}^{1}$ iD, C. Montomoli', iD, J. M. $\operatorname{Cottle}^{3}$ iD, and R. D. Law ${ }^{4}$ iD \\ ${ }^{1}$ Dipartimento di Scienze della Terra, Università di Torino, Turin, Italy, ${ }^{2}$ IGG-CNR PISA, Pisa, Italy, ${ }^{3}$ Department of Earth \\ Science, University of California, Santa Barbara, CA, USA, ${ }^{4}$ Department of Geosciences, Virginia Polytechnic Institute \\ and State University, Blacksburg, VA, USA
}

Abstract Despite the Mediterranean sector of the Variscan Belt being fragmented and reworked during Alpine orogenesis, evidence for the activity of a right-lateral strike-slip shear zone has been reported in Paleozoic fragments of the belt such as the Sardinian Variscan Basement, the Maures Massif of southern France, and in the Western Alps. To improve this correlation with new structural data, we performed a structural and microstructural analysis incorporating study of the kinematics of flow and petrochronology of a high-strain zone in the Aiguilles Rouges Massif (External Crystalline Massifs, Western Alps). The results higlight a dextral pure-shear dominated transpression initiated under amphibolite-facies metamorphic conditions $\left(\sim 630^{\circ} \mathrm{C}, 0.4 \mathrm{GPa}\right)$ during Variscan time. The structural evolution of the high-strain zone is similar to the Ferriere-Mollières shear zone in the Argentera Massif; both are transpressive shear zones active at the same time ( $320 \mathrm{Ma})$ under similar metamorphic conditions. These two high-strain zones represent well-preserved segments of a system of ductile shear zones in the External Crystalline Massifs. The data presented in this study provide improved constraints on the extent, kinematics, and timing of the East Variscan Shear Zone in the Variscan basement of the Western Alps, with implications for refining the correlation between structures in fragments of the southern Variscan Belt. The data also better constrain a segment of a major pre-Alpine shear zone which may have played an important role during post-Variscan tectonics as an inherited discontinuity.

\section{Introduction}

The longevity of orogenic belts is controlled by factors such as erosion and isostatic equilibration, post-collisional extension, and both indentation and transpressional tectonics. Indentation tectonics (Davy \& Cobbold, 1988; Tapponnier \& Molnar, 1977) caused by continuing convergence after collision strongly affects the evolution of the lateral portions of the indented belt. A classical example of indentation tectonics is provided by the collision between India and Asia. In the Himalaya, the Chaman Fault on the west and the Sagaing Fault on the east act as tracks facilitating the northward indentation of India into Eurasia (Tapponnier et al., 1982; Tapponnier \& Molnar, 1977).

Fundamental parameters that control these phenomena include rheology of the colliding blocks and the dimension and state of confinement. The kinematics of deformation along the regional-scale structures are variable, depending on the sector of the indented belt in which they are developed. Typically, faults and shear zones developed at the two lateral margins of the indenter are characterized by transpressional deformation and opposite senses of shear. The consequence of this process is the formation of large-scale orogenic curvature known as an orocline (Bajolet et al., 2013; Carey, 1955; Rumelhart et al., 1999). Several mountain belts, such as the New England Orogen (Glen \& Roberts, 2012; Li et al., 2012; Li \& Rosenbaum, 2014), the Wyoming Salient (Johnston et al., 2013) in the Sevier thrust belt (United States), the Carpathian-Balkan segment (Shaw \& Johnston, 2012) of the Alpine orogen (southeastern Europe), and the European Variscides (García-Navarro \& Fernández, 2004; Matte, 1986a, 1986b; Pastor-Galán et al., 2012; Pastor-Galán, Ursem, et al., 2015; Pastor-Galán et al., 2015; Pereira et al., 2008), exhibit large-scale orogenic curvatures. The shape of the Variscan Belt in Europe (Figure 1a), the result of Devonian-Carboniferous continent-continent collision between Laurentia-Baltica and Gondwana (Arthaud \& Matte, 1977; Burg \& Matte, 1978; Matte, 1986b, 2001; Tollmann, 1982), is characterized by a 


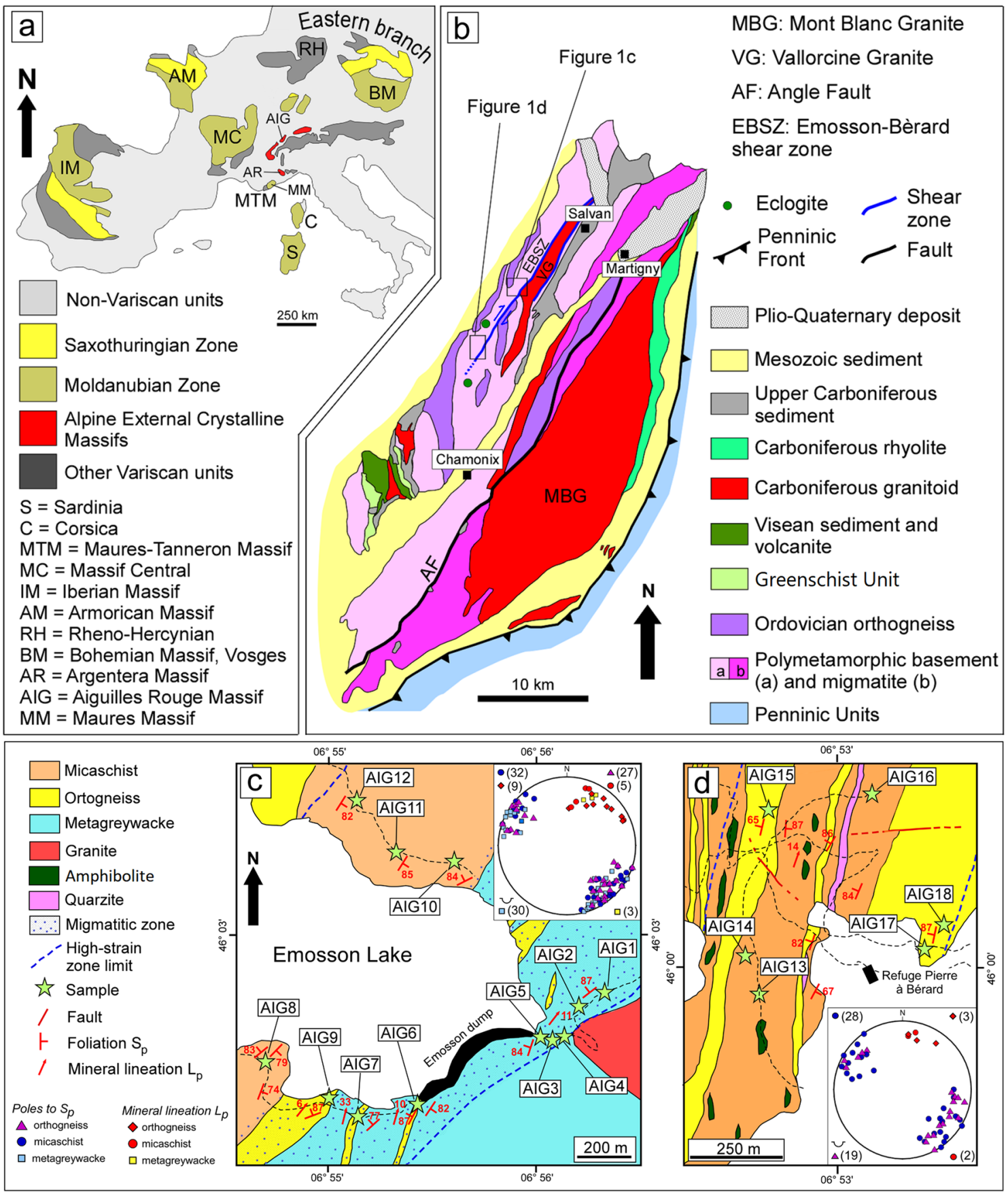

Figure 1. (a) Variscan units in Europe and (b) sketch map of the Aiguilles Rouges and Mont Blanc Massifs located on the north and south sides of the Chamonix Valley, respectively (modified after Compagnoni et al., 2010); (c) sketch map of the Emosson Lake area and measured structural elements; (d) sketch map of the Val Bérard area and measured structural elements (modified after Von Raumer \& Bussy, 2004).

composite orocline containing two large-scale arcs (Matte, 1986a, 1986b; Matte \& Ribeiro, 1975): a western branch known as the Ibero-Armorican arc (Brun \& Burg, 1982; Dias et al., 2016; Dias \& Ribeiro, 1995; Fernández-Lozano et al., 2016; Matte \& Ribeiro, 1975), and a smaller eastern branch (Ballèvre et al., 2018; Bellot, 2005; Matte, 2001) delimited by a regional-scale dextral transpressive shear zone, known as the East Variscan Shear Zone (EVSZ; Carosi et al., 2012; Corsini \& Rolland, 2009; Guillot \& Ménot, 2009; Padovano et al., 2014, 2012; Rolland et al., 2009; Simonetti et al., 2018). This has led some authors (Dias et al., 2016; Kroner \& Romer, 2009, 2013; Matte, 2001; Rolland et al., 2009; Simonetti, Carosi, \& 
Montomoli, 2018) to hypothesize that the Variscan Belt in Europe evolved in a manner analogous to the indentation model for the Himalaya.

The EVSZ is imperfectly understood, especially in those sectors of the Variscan Belt now preserved in the Alps (Figure 1a), and its role during Variscan and post-Variscan times is still debated. According to some authors, the EVSZ is related to the transition from Pangea B to Pangea A that started during Permian (Muttoni et al., 2009, 2003).

The Wegenerian configuration of Pangea (Pangea A) is the widely accepted post-Variscan paleogeographic scenario (van der Voo, 1993), but paleomagnetic analysis concluded that, with this reconstruction, overlap of continental crust between Gondwana and Laurentia-Baltica occurred in the Early Permian. Muttoni et al. (1996) proposed placing Gondwana to the east, maintaining the coherence of the paleomagnetic poles and in agreement with the Irvinian Pangea B configuration. According to this model, Pangea B finally transformed into Pangea A by the end of the Permian and the movement of Gondwana was accomodated by a crustal-scale system of dextral strike-slip structures. However, it is not clear which structures would have allowed the movement of Gondwana and if their remnants are still recognizable. Some authors proposed as evidence the extensive presence of pre-Alpine dextral shear in the fragments of the Variscan Belt such as the Alpine External Crystalline Massifs (ECM) and the formation of Early Permian basins.

Geochronological data from pre-Alpine shear zones in the Western Alps point to an older deformation still related to the Variscan orogeny (Pohl et al., 2018; Simonetti, Carosi, \& Montomoli, 2018), suggesting that activity on the EVSZ is not related to post-Variscan events. A detailed structural and geochronological analysis of the shear zones in the Variscan basement of the Western Alps is therefore necessary to address this problem.

Another remaining question concerns the lateral relationships between the Corsica-Sardinia Block (CSB), the Maures-Tanneron Massif, and the Variscan basement of the Western Alps. The correlation between those sectors is debated and is mostly based on lithological and stratigraphic affinities and paleomagnetic data. In particular, it is not clear if the CSB was connected to Iberia (Stampfli et al., 2002; Turco et al., 2012) or to southern France (Advokaat et al., 2014; Rosenbaum et al., 2002) during late Carboniferous times. A deeper knowledge of the different phases of Variscan deformation, and their ages, is of fundamental importance for improving correlation between the dispersed fragments of the Variscan Belt in the Mediterranean area.

In the Western Alps, the ECM are cross-cut by km-scale shear zones whose age(s) of tectonic activity and deformation regime are not always clear. In the present work, we focus on two areas within the Aiguilles Rouges Massif (ARM) where rocks are strongly sheared along a thick belt of mylonites (Von Raumer \& Bussy, 2004) and Alpine deformation is very weak (Dobmeier \& von Raumer, 1995; Pilloud, 1991). The aim of this study is to clarify both the kinematics of the flow and to constrain the age of the deformation in order to verify if they are similar to tectonic interpretations previously proposed for the Argentera Massif and for other fragments of the Variscan Belt in the Mediterranean area. We carried out a kinematic vorticity analysis and a U-Th-Pb petrochronological study on monazites, combined with structural and microstructural analyses of sheared rocks recognized by Von Raumer and Bussy (2004) and Genier et al. (2008).

\section{Geological Setting of the Aiguilles Rouges Massif}

The ARM is located on the boundary between Switzerland and France and belongs to the ECM of the Western Alps (Figure 1a) that represent fragments of the Moldanubian internal zone of the Variscan Belt caught up in subsequent Alpine orogenesis.

An Alpine greenschist-facies overprint $\left(\nmid 0.5 \mathrm{GPa}, 400^{\circ} \mathrm{C}\right)$ is recognized in the nearby Mont Blanc Massif (Figure 1b) where a network of shear zones reworked the Late Variscan Mont Blanc granite (Rolland et al., 2003; Rossi et al., 2005). In contrast, in the ARM, Alpine metamorphism remained very localized and reached temperatures lower than $\sim 320^{\circ} \mathrm{C}$ (Boutoux et al., 2016), thus above the brittle-ductile transition zone and thereby allowing widespread preservation of the Variscan shear zones and their microstructures and crystal fabrics. 
The ARM (Figure 1b) is composed of metamorphosed pelitic schists, paragneiss, orthogneiss, and migmatite intruded by Carboniferous age granitoids (Von Raumer \& Bussy, 2004).

Most of the Variscan tectono-metamorphic evolution of the ARM occurred during a time span of $~ 25 \mathrm{Myr}$ (Von Raumer et al., 2003). A first stage of thrusting induced prograde Barrovian metamorphism (Von Raumer et al., 1999) and nappe stacking during collision and crustal thickening (Dobmeier, 1998). Subsequently, the massif underwent strike-slip transpression followed by gravitational collapse (Von Raumer \& Bussy, 2004). Peak Variscan metamorphism in the ARM reached high amphibolite-facies conditions. A U-Pb age on monazite of $327 \pm 2 \mathrm{Ma}$ is interpreted to date the near-peak conditions. Locally anatexis occurred at $\sim 320$ Ma during high $\mathrm{T}$ decompression (Bussy et al., 2000; Genier et al., 2008). The tectono-metamorphic evolution of the massif is also characterized by two magmatic pulses at $\sim 330 \mathrm{Ma}$ and $\sim 307$ Ma (Bussy et al., 2000; Von Raumer \& Bussy, 2004). The first pulse is represented by high-K calc-alkaline to shoshonitic plutons that crop out in the southern part of the massif (Pormenaz monzonite and Montées Pélissier granite; Bussy et al., 2000); the second pulse was responsible for syn-tectonic emplacement of sheet-like peraluminous granites (Vallorcine granite, Fully granodiorite, Montenverse granite; Bussy et al., 2000; Genier et al., 2008; Von Raumer \& Bussy, 2004).

The crystalline basement rocks of the massif are overlain by late Carboniferous coarse-grained clastic sedimentary rocks deposited in a post-collisional strike-slip tectonic regime and affected by Alpine deformation (Capuzzo et al., 2003). Volcanic deposits within the sediments are dated to the late Carboniferous (Capuzzo $\&$ Bussy, 2001), with an age of $308 \pm 3 \mathrm{Ma}$ for basal dacitic flows and of $295 \pm 3 \mathrm{Ma}$ for a tuff layer from the upper levels of the basin sequence. The Carboniferous rocks are overlain by a Mesozoic sedimentary sequence.

Shear deformation represents an important feature of Variscan basement in this area. The Angle Fault (Figure 1b) is a major shear zone that divides the massif into two portions, each with its own sedimentary cover: an internal portion, essentially granitic, located to the east, and a more composite external portion to the northwest (Epard, 1990). The Angle Fault probably developed as a shear zone during late Variscan strike-slip shearing and was later brittly reactivated during the Alpine orogeny (Von Raumer \& Bussy, 2004). In the northwest portion of the massif several steeply dipping strike-slip ductile shear zones, striking NNE-SSW, are present (Genier et al., 2008; Von Raumer \& Bussy, 2004). Some of these shear zones were probably active during late Carboniferous sedimentation and volcanism (Capuzzo \& Bussy, 2001).

In the Emosson Lake area and along its SW extension (Figures 1b-1d), the Val Bérard area, a $\sim 500 \mathrm{~m}$ thick high-strain mylonitic zone developed in metasediment and orthogneiss (Genier et al., 2008; Von Raumer \& Bussy, 2004). Mylonites truncate the late Variscan Vallorcine granite (Figures $1 \mathrm{~b}$ and 1c). The southeastern side of the same granite is truncated by another ductile shear zone (Figure 1b) known as the Miéville Ultramylonite (Kerrich et al., 1980; Von Raumer \& Bussy, 2004). Subvertical N-S to NE-SW trending folds, with hinges oriented parallel to the main foliation of the high-strain zone, occur in the unsheared rocks (Von Raumer, 1984; Von Raumer \& Schwander, 1985). Partial melting at the expense of micaschists and metapelites within the shear zone has been interpreted to be induced by the addition of channeled external water (Genier et al., 2008; Von Raumer \& Bussy, 2004).

\section{Structural and Microstructural Analysis}

We performed a meso-structural analysis, combined with microstructural studies on field-oriented samples collected along two parallel NW-SE transects across the Emosson-Bérard shear zone: One transect is in the Lake Emosson area (Figure 1c), and the other is in the Val Bérard area (Figure 1d). Samples were cut perpendicular to the main foliation and parallel to the mineral stretching lineation (assumed XZ section of the finite strain ellipsoid).

\subsection{Emosson Lake Area}

In the Lake Emosson area the high-strain zone, oriented NE-SW, is made of micaschist and metagraywake alternating with orthogneiss (Figure 1c). The main subvertical foliation $\mathrm{S}_{\mathrm{p}}$, both in the metasediment and in the orthogneiss, strikes NE-SW (Figure 1c). In the metagraywake (Figure 2a) foliation is a fine-grained continuous cleavage (Figure 2b) defined mainly by white mica and chloritized biotite. The micaschist (Figure 2c) is characterized by a spaced foliation with zonal cleavage domains (Figure 2d) defined by 

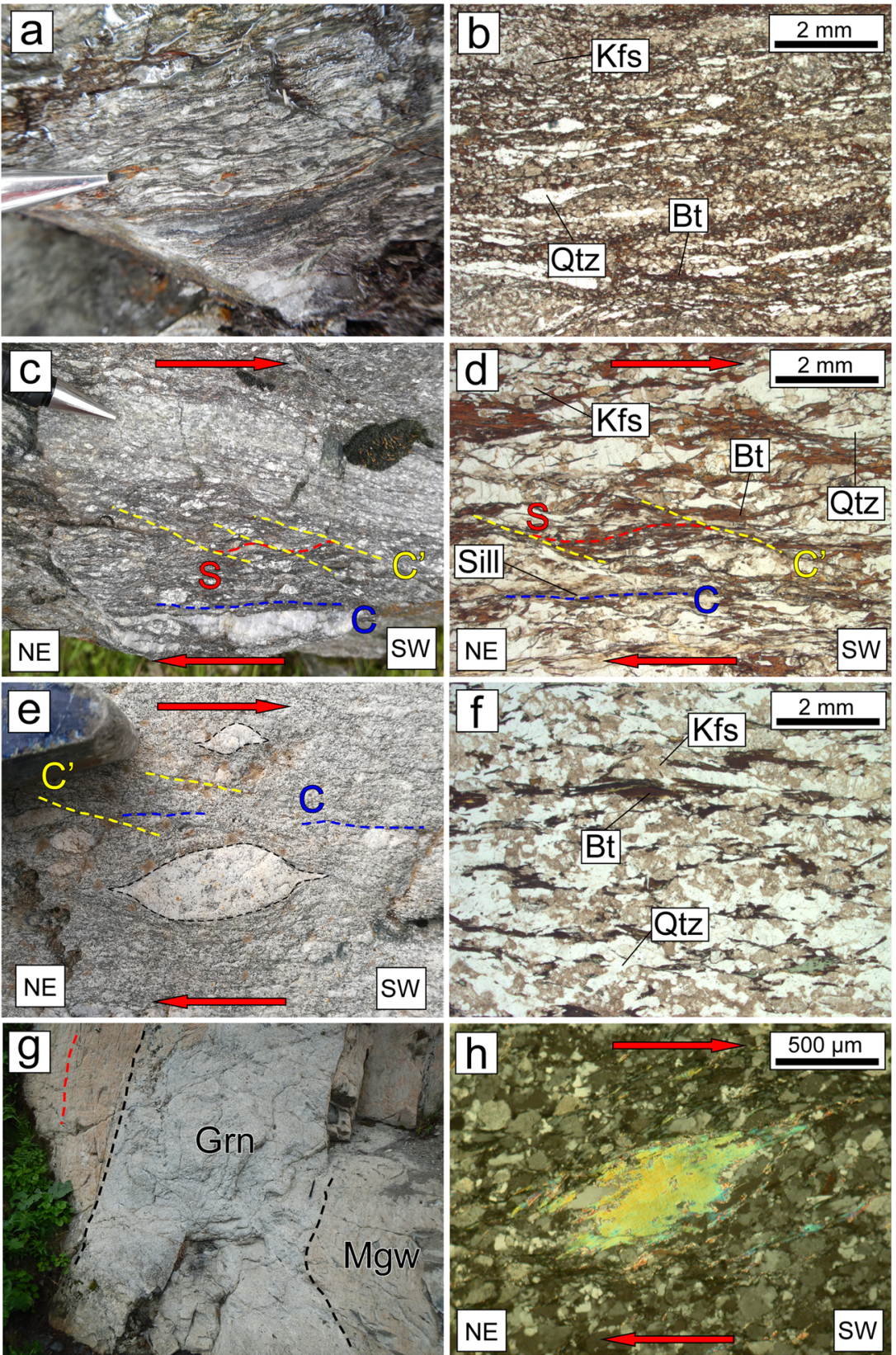

Figure 2. (a) Mylonitic metagraywacke (Emosson Lake); (b) continuous cleavage in metagraywacke (parallel nicols); (c) S-C-C' fabric in micaschist (Val Bérard); (d) S-C-C' fabric in micaschist (parallel nicols); (e) S-C-C' fabric and $\sigma$-type K-feldspar porphyroclast in orthogneiss (Val Bérard); (f) anastomosing disjunctive foliation in orthogneiss (parallel nicols); (g) granitic dike (Grn) intruded along main foliation cutting metagraywacke (Mgw); (h) white mica micafish in the metagraywacke (crossed nicols). Mineral abbreviations after Kretz (1983).

chloritized biotite and fibrolitic sillimanite; microlithons are mainly made of quartz and feldspar. Garnet porphyroclasts are present. A mineral lineation $\mathrm{L}_{\mathrm{p}}$, plunging gently toward the NE (Figure 1c), occurs on the foliation and is defined by aligned biotite and sillimanite crystals. In the orthogneiss (Figure 2e) an anastomosing disjunctive foliation (Figure 2f) defined by partially chloritized dark-brown biotite is observed. Microlithons are mainly made of quartz and feldspar. A mineral lineation $\mathrm{L}_{\mathrm{p}}$, made by elongated feldspar, plunges gently toward the NE (Figure 1c). Close to the Vallorcine granite, granitic dikes (Figure 2g), composed of quartz, plagioclase, feldspar, and white mica, are intruded along the main foliation in the metagraywacke and are cut by a poorly developed subvertical N-S foliation. Kinematic 
indicators such as C- and $\mathrm{C}^{\prime}$-type shear bands (Figures $2 \mathrm{c}$ and $2 \mathrm{~d}$ ) and micafish (Figure $2 \mathrm{~h}$ ) in the metasediments and $\sigma$-type mantled feldspar porphyroclasts in both micaschist and orthogneiss indicate a dextral sense of subhorizontal shear viewed geographically downwards.

\subsection{Val Bérard Area}

Similarly to the Lake Emosson area, sheared garnet-bearing micaschist, interlayered with orthogneiss, occurs (Figure 1d). Quarztite and amphibolite bodies embedded within the sheared micaschist are also present. The main subvertical foliation $S_{p}$ in the micaschist and orthogneiss strikes NE-SW (Figure 1d). The micaschists, very similar to those observed in the Lake Emosson area, are characterized by a spaced foliation with zonal cleavage domains defined by chloritized biotite and fibrolitic sillimanite. Microlithons defined by quartz and feldspar and garnet porphyroclasts are present. In the orthogneiss the main foliation is an anastomosing disjunctive foliation defined by biotite, while microlithons are mainly composed of quartz and feldspar. A mineral lineation $\mathrm{L}_{\mathrm{p}}$, defined by biotite and elongated feldspars, plunges gently to the $\mathrm{NE}$ (Figure 1d). Kinematic indicators such as S-C and S-C' fabrics in the micaschists and $\sigma$-type cm-scale mantled K-feldspar porphyroclasts in the orthogneiss (Figure 2e) indicate a dextral sense of shear viewed geographically downwards.

\subsection{Quartz Microstructures and Fabrics}

In the analyzed samples, collected in both the orthogneiss and the metasedimentary rocks, quartz is generally coarse-grained with lobate grain boundaries (Figures $3 \mathrm{a}$ and $3 \mathrm{~b}$ ) and locally developed window structures (Figure 3c). These quartz microstructures indicate that grain boundary migration (GBM) is the dominant mechanism for dynamic recrystallization. Some grains are bounded by tilt walls (Figure 3d) and in a few grains incipient chessboard extiction microstructures are present (Figure 3e). Especially in the metasedimentary rocks, quartz subgrains are also observed, with new quartz grains of smaller size surrounding the larger grains (Figure 3f) forming a "core and mantle structure" (White, 1976) and generating a weakly bimodal grainsize. These microstructures are indicative of incipient subgrain rotation recrystallization (SGR) overprinting the grain boundary migration (GBM) microstructures.

Plastically deformed quartz grains in granitic dikes display undulose extinction and have a weakly bimodal recrystallized grainsize. A few grains have lobate grain boundaries (Figure 3g) while in most samples core and mantle microstructures are observed (Figure $3 \mathrm{~h}$ ). These microstructures are indicative of SGR as the main mechanism of dynamic recrystallization. Quartz c-axis fabrics were measured in samples AIG3, AIG6, AIG7, and AIG8 (Figure 4a), from Lake Emosson area, and in samples AIG16, AIG17, and AIG18 (Figure 4b), from Val Bérard area. Fabrics were measured using a universal stage, with a minimum of 500 grains analyzed in each thin section.

Sample AIG6 is characterized by a fabric that is transitional between a Type-I and a Type-II cross-girdle fabric (Lister, 1977). Samples AIG3, AIG7, AIG8, AIG16, AIG17, and AIG18 are characterized by Type-II crossgirdle fabrics. Most of the fabrics are asymmetrical in terms of density distribution and a leading edge of the fabric skeleton is recognizable (Law, 2014; Xypolias et al., 2013). All measured quartz fabrics have a weak external asymmetry with respect to foliation and lineation highlighted by the different magnitudes of the angles $\mathrm{C} 1$ and $\mathrm{C} 2$ (Figure 4), measured in the XZ plane, between the foliation pole $(\mathrm{Z})$ and the leading and trailing edges, respectively, of the fabric skeleton (Law, 2014).

These fabric asymmetries are all indicative of a non-coaxial deformation (Law, 1990; Schmid \& Casey, 1986), with a prevalent pure shear component, associated with a dextral sense of shear viewed vertically downwards on to the subhorizontal XZ plane, in agreement with all microstructural shear sense indicators. The topology of the transitional Type-I to Type-II cross-girdle c-axis fabrics suggests that shearing occurred under conditions close to plane strain (Lister \& Hobbs, 1980; Schmid \& Casey, 1986).

\section{Temperature of Deformation}

To estimate deformation temperatures during shearing, we used a range of different techniques: the mineral assemblage on the mylonitic foliation $S_{\mathrm{p}}$, quartz microstructures (Stipp et al., 2002), and the opening angles of quartz c-axis fabric (Faleiros et al., 2016; Kruhl, 1998; Law et al., 2004). Experimental (Tullis et al., 1973) 

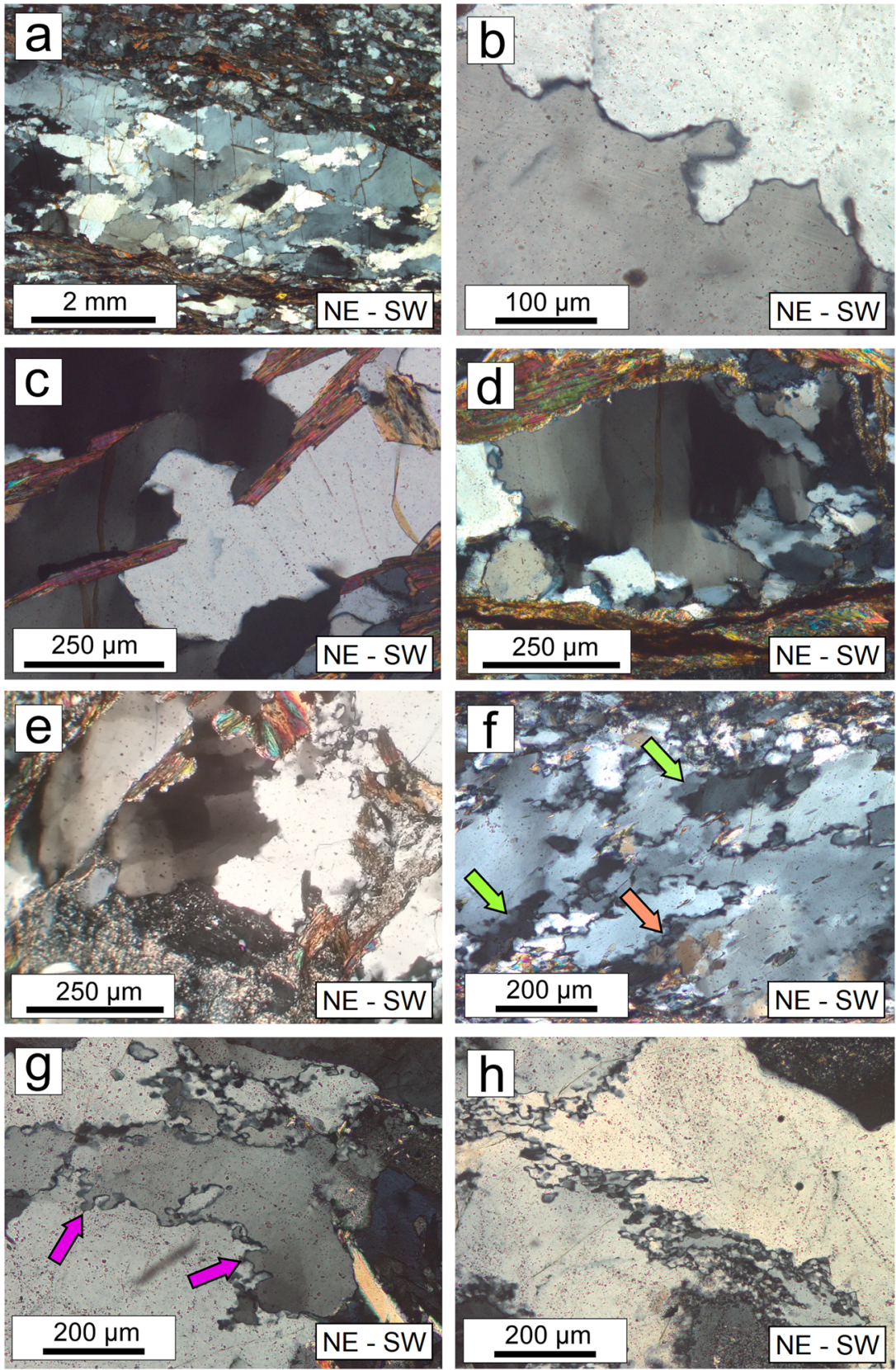

Figure 3. Quartz microstructures (crossed nicols) (a) coarse-grained quartz with lobate grain boundaries in micaschists; (b) detail of a lobate grain boundary; (c) window structure; (d) quartz grain with internal tilt walls; (e) quartz grain with incipient chessboard extinction pattern; (f) quartz subgrains (green arrow) and small new grains (pink arrow) around older coarser grains; (g) quartz in granitic dike with lobate grain boundaries (violet arrows); (h) bimodal grainsize of quartz in granitic dike.

and numerical simulation studies (Lister \& Dornisiepen, 1982; Lister \& Hobbs, 1980) indicate that during plastic deformation and dynamic recrystallization, the opening angle of quartz c-axis fabrics increases with rising deformation temperature, increasing hydrolytic weakening, and decreasing strain rate. The opening angle is the angle between the two c-axis girdles measured in the plane perpendicular to foliation and parallel to lineation (Kruhl, 1998; see review by Law, 2014). At natural strain rates there is an approximately linear increase in opening angle with temperature between approximately $300^{\circ} \mathrm{C}$ and $650^{\circ} \mathrm{C}$, with a nominal uncertainty usually stated at $\pm 50^{\circ} \mathrm{C}$ (Kruhl, 1998). Faleiros et al. (2016) proposed a new calibration extending the correlation between opening angle and temperature above $650^{\circ} \mathrm{C}$. 

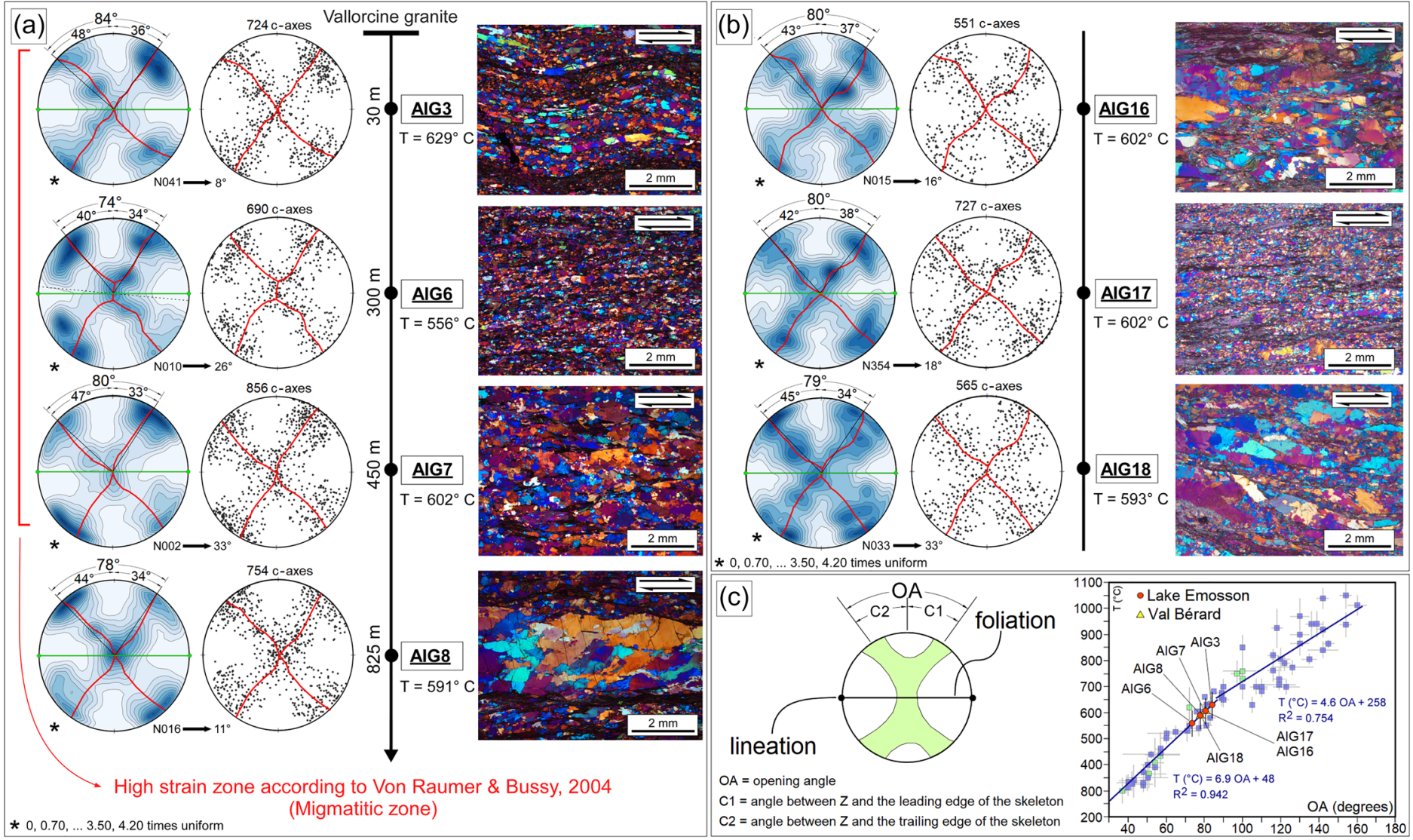

Figure 4. Optically measured quartz c-axis fabrics and recrystallization microstructures of samples from (a) Emosson Lake area and (b) Val Bérard area. Pole figures and micrographs are oriented perpendicular to foliation and parallel to lineation. Trend and plunge of mineral lineation in individual samples and distances from the Vallorcine granite are indicated. Dashed line is parallel to the shear plane, green line is parallel to the main foliation and green dots are parallel to mineral lineations. Best-fit fabric skeletons indicated by red lines; note that $\mathrm{C} 1<\mathrm{C} 2$ in all fabrics, confirming dextral shear sense. (c) Faleiros et al. (2016) quartz c-axis fabric opening-angle thermometer, blue squares are data with pressure information used to define the thermometer, while green square are data used by Faleiros et al. (2016) that have no pressure information. Equations that describe linear fits are reported.

The syn-kinematic minerals on the mylonitic foliation include biotite and fibrolitic sillimanite in the micaschist and dark-brown biotite in the orthogneiss. In the Emosson Lake area the metagraywakes contain syn-kinematic biotite and white mica. Syn-kinematic assemblages indicate amphibolite-facies metamorphic conditions. Quartz microstructures are indicative of grain boundary migration (GBM) as the dominant recrystallization mechanisms in all the studied samples. Taken together, mineral assemblages and quartz microstructures indicate a likely deformation temperature range of $500^{\circ} \mathrm{C}$ to $700^{\circ} \mathrm{C}$.

Measured c-axis fabric opening angles in samples collected in the Emosson Lake (Figure 4a) area indicate moderately high-temperature deformation conditions ranging from $\sim 550^{\circ} \mathrm{C}$ to $630^{\circ} \mathrm{C}$ (Figure 4c). Samples collected in the sector of the high-strain zone affected by partial melting exhibit the highest opening angle values and inferred deformation temperatures. The inferred deformation temperatures decrease slightly traced toward the NW, away from the migmatitic zone (Figure 4a).

The opening angles of c-axis fabrics for samples collected in the Val Bérard area are also indicative of moderately high deformation temperatures of $\sim 600^{\circ} \mathrm{C}$ (Figure $4 \mathrm{~b}$ ). Quartz fabrics also provide insights on crystallographic slip systems active in the deforming crystal, with fabric point maxima in all the samples analyzed indicating prism [a], romb [a], and basal [a] slip. We did not detect any fabric point maxima evidence for higher temperature $\left(>630^{\circ} \mathrm{C}\right.$ to $\left.650^{\circ} \mathrm{C}\right)$ prism [c] slip, although the presence of quartz chessboard extinction microstructures in some samples (AIG16, AIG18; Figure 3e) indicates that prism [c] slip is at least locally important. 


\section{Kinematic Vorticity}

Kinematics of flow, that is, the components of pure and simple shear acting simultaneously during deformation (see Fossen \& Cavalcante, 2017; Xypolias, 2010, for reviews) in the high-strain zone, and expressed by the kinematic vorticity number $\mathrm{Wk}$, were estimated using two independent kinematic vorticity gauges: the $C^{\prime}$ shear band method (Gillam et al., 2013; Kurz \& Northrup, 2008) and the stable porphyroclast method (Passchier, 1987; Wallis et al., 1993). For a description of the methods and their assumptions (Jeffery, 1922; Platt \& Vissers, 1980; Simpson \& de Paor, 1993), see supporting information S1. Analyses were performed on thin section cut perpendicular to foliation and parallel to lineation (i.e., the inferred $\mathrm{XZ}$ plane of the finite strain ellipsoid). Pure shear is indicated by Wk $=0$, and simple shear by $\mathrm{Wk}=1$. Simple and pure shear contribute equally to flow for a value of Wk $=0.71$ (Law et al., 2004; Xypolias, 2010).

The nominal error for vorticity analysis is \pm 0.1 (Tikoff \& Fossen, 1995). Comparison of different possible systematic error sources indicates that for medium to low vorticity numbers $(\mathrm{Wm}<0.8)$, vorticity data are strongly biased and that a minimum systematic error of 0.2 is more realistic (Iacopini et al., 2011). It is also important to consider the possible error caused by volume loss on kinematic vorticity analysis, although this is likely to be minor with respect to the error in the vorticity method itself (Fossen \& Cavalcante, 2017). In order to check the type of deformation we calculated the angles $\theta$ between the maximum Instantaneous Stretching Axis (ISA max) in the horizontal plane and the shear zone boundary. This parameter is fundamental for distinguishing between transpression and transtension (Fossen et al., 1994; Fossen \& Tikoff, 1993). The calculation was performed using the formula $\theta=(\arcsin \mathrm{Wk}) / 2$ (Xypolias, 2010).

\subsection{Results of Vorticity Analysis}

Full datasets are reported in supporting information (Figure S1). An example of a polar histogram showing the measured angle $v$ between the $\mathrm{C}^{\prime}$ and the $\mathrm{C}$ planes parallel to the shear zone boundaries is shown in Figure $5 \mathrm{a}$. The histograms were used to derive the angle $2 v$ between the apophyses A1 and A2.

An example of a preliminary Mulchrone test (Mulchrone, 2007a, 2007b), which is needed to determine if slip occured between clasts and matrix (Iacopini et al., 2011, and reference therein; see supporting information S1), and a graph showing porphyroclasts distribution used in the stable porphyroclasts method are reported in Figures $5 \mathrm{~b}$ and 5c, respectively. From the compiled Mulchrone diagrams, our data do not fit the theoretical curve calculated for a system in which slip between porphyroclasts and matrix occurs. Furthermore, selected feldspars are free to rotate in the matrix without mutual interference because the distance between porphyroclasts is larger than their maximum long axis.

Vorticity analysis with the $\mathrm{C}^{\prime}$ shear band method gives Wk values varying between 0.34 and 0.74 (Figure S1). In general, Wk may vary according to the rock type but is quite constant for samples of the same rock type collected in our two study areas. Samples AIG8 and AIG12, micaschists of the Emosson Lake area, yield Wk values of 0.55 and 0.52. Samples AIG2 and AIG3, metagraywakes from the same area, yield Wk value of Wk of 0.55 and 0.66, respectively. Samples AIG14 and AIG16 from the garnet-bearing micaschists of the Val Berard area yield Wk values of 0.58 and 0.61 , respectively.

In contrast to the micaschist samples, Wk values from the orthogneisses are slightly lower. Samples AIG9 and AIG6, from the Emosson Lake area, yield Wk of 0.40 and 0.34 , respectively (Figure S1) while in samples AIG15, AIG17, and AIG18 from the Val Bérard area, Wk values are estimated at 0.43, 0.40, and 0.46, respectively.

Wk values are all indicative of a general shear deformation with synchronous components of both pure and simple shear. The estimated percentage of pure shear component varies between 77\% and 53\% (Figure 5d). In the orthogneiss the percentage of pure shear is always higher compared to the micaschists and the metagraywakes (Figure 5d).

Vorticity analysis using the stable porphyroclasts method on the orthogneiss of the Emosson Lake area yield an estimated Wm value of 0.54 (Figure S1) whereas the Wm value obtained on the orthogneiss of the Val Bérard area is 0.44 (Figure S1). These values are indicative of a percentage of pure shear component between $62 \%$ and $70 \%$. The datasets collected in the orthogneiss using the two methods are well comparable. 

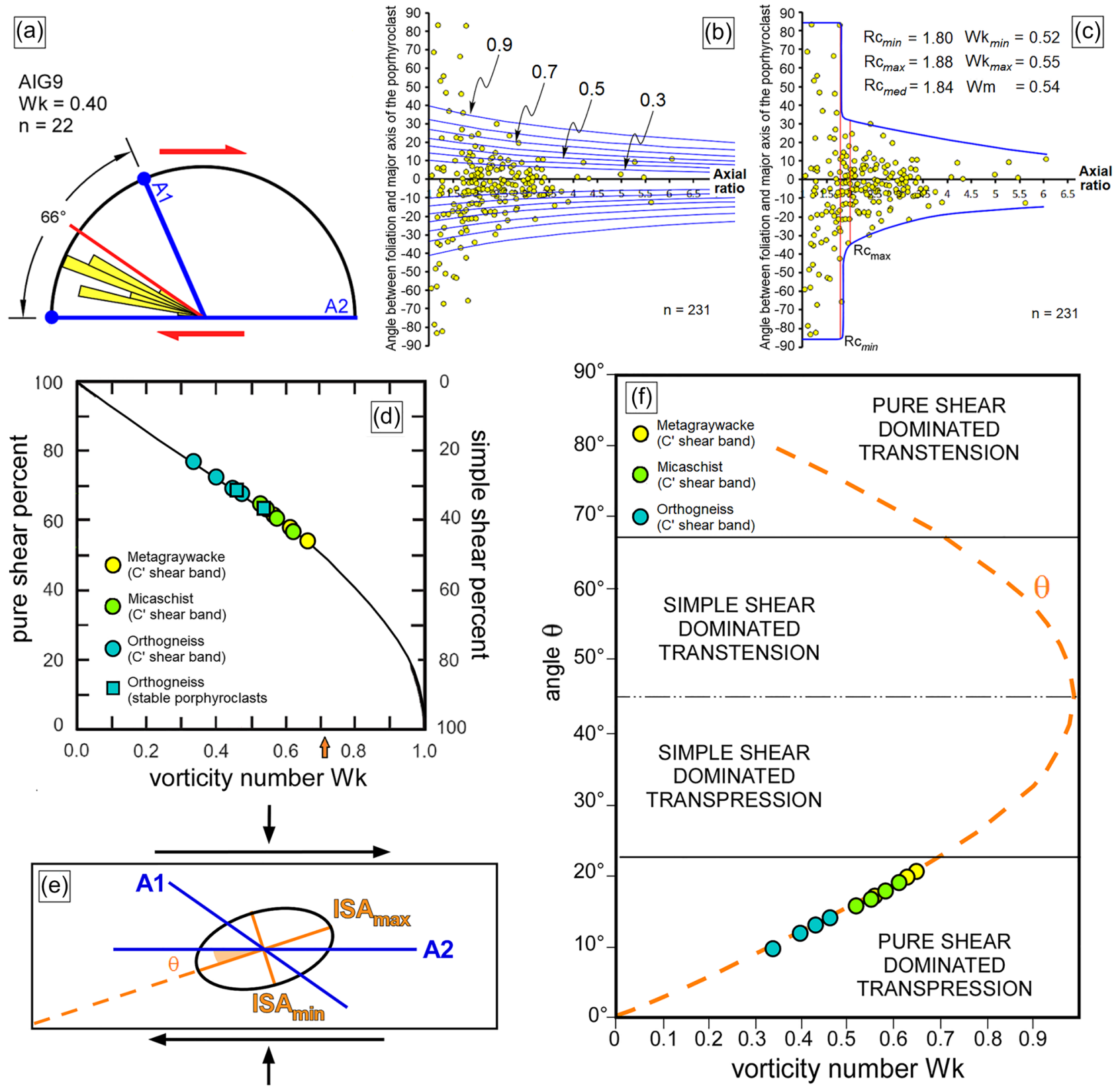

Figure 5. (a) Example of polar histogram used with the $\mathrm{C}^{\prime}$ shear band method. Yellow bars represent number of data; (b) Mulchrone test for dataset collected in the Val Bérard, blue lines represent the expected distribution of data at different vorticity numbers in the presence of a clast/matrix slipping interface;

(c) example of graph used to determine the critical axial ratio (stable porphyroclast method); (d) results of vorticity analyses, arrow points to Wk $=0.71$ (equal contribution of simple and pure shear); (e) orientations of the instantaneous flow elements in a dextral shear zone with non-coaxial deformation. $\theta$ : Angle between $\mathrm{ISA}_{\max }$ and shear zone boundaries; (f) relationships between angle $\theta$ and $\mathrm{Wk}$.

Calculated $\theta$ angles between the maximum Instantaneous Stretching Axis (ISA max) in the horizontal plane and the shear zone boundary (Figure $5 \mathrm{e}$ ) vary between $\sim 20^{\circ}$ and $9^{\circ}$ (Figure $5 \mathrm{f}$ ). These values, combined with the vorticity numbers estimated above, are indicative of a pure shear-dominated transpression (Figure 5f).

\section{Petrochronology}

In situ U-Th- $\mathrm{Pb}$ dating was performed, following the procedure outlined by Montomoli et al. (2013), on eight monazites selected in three sheared samples of micaschist collected within the high-strain zones. Thirty-eight individual spots were analyzed on polished thin sections. Analytical methods used in this 
study follow those outlined in Kylander-Clark et al. (2013) with modifications outlined in McKinney et al. (2015). The full procedure of data normalization (Aleinikoff et al., 2006) and data accuracy control (Horstwood et al., 2003) is described in supporting information S1 as well as the used decay constants (Amelin \& Zaitsev, 2002; Jaffey et al., 1971). Samples AIG8 and AIG11 were collected in the Emosson Lake area while sample AIG14 was from the Val Bérard area. A fundamental requirement for interpreting the REE patterns in monazite is the presence of garnet in the rock. This allows us to use chemical proxies, like $\mathrm{Y}+$ HREE zoning and REE patterns, coupled with grain textural position and zoning in order to guide the interpretation of monazite data with respect to the prograde and/or retrograde stages of metamorphism.

Garnet has a major control on the HREE and Y budget in these systems (Engi et al., 2017 and references therein), and in a closed system, its growth will consume HREE and Y from the environment and thus reduce the avaibility of these elements for monazite growth (Buick et al., 2006; Foster et al., 2002; Hermann \& Rubatto, 2003; Rubatto et al., 2006). In contrast, garnet breakdown will release HREE and Y, which can then be redistributed in monazite growing at the same time. Therefore, during retrograde metamorphism, Y tends to preferentially be sequestered by monazite resulting in increasing values of HREE and Y (Iaccarino et al., 2017; Pyle et al., 2001; Pyle \& Spear, 1999; Williams et al., 2007).

Analysis of the microstructural monazite positions, and measured chemical composition of the monazite in the petrologic system in which they are associated with adjacent garnet grains, allows us to determine the tectono-metamorphic history at which the two phases have grown. Because our microstructural studies indicate that penetrative deformation occurred during decreasing temperature conditions (Von Raumer \& Bussy, 2004), we interpret the Y zoning in the monazite to reflect retrograde metamorphic conditions.

\subsection{Monazites Characterization and U-Th-Pb Analysis Results}

Dated monazite grains are broadly divided in two groups: a first group composed of grains included in garnet (Mnz10 in sample AIG11) or biotite porphyroclasts (spot position Mnz34 in sample AIG11) and a second group of grains located within the main foliation (Mnz3, Mnz52, Mnz10, Mnz11 in sample AIG8; Mnz2 in sample AIG14; Mnz37 in sample AIG11). The two groups differ in terms of chemical characteristics. Chemical EPMA analysis and spots positions are reported in supporting informations (Table S1 and Figure S2, respectively).

$\mathrm{Y}$ content is low in monazite included in porphyroclasts $\left(\mathrm{Y}_{2} \mathrm{O}_{3}\right.$ between $\sim 0.11$ and $\left.\sim 0.18 \mathrm{wt} \%\right)$ and is higher in grains located in the main foliation $\left(\mathrm{Y}_{2} \mathrm{O}_{3}\right.$ between $\sim 1.04$ and $\left.\sim 2.74 \mathrm{wt} \%\right)$. Spot position Mnz37 in sample AIG11 and Mnz2 in sample AIG14, both in grains located within the main foliation, have a Y zoning with low-Y cores $\left(\mathrm{Y}_{2} \mathrm{O}_{3}\right.$ between $\sim 0.17$ and $\left.\sim 0.72 \mathrm{wt} \%\right)$ and high- $\mathrm{Y}$ rims $\left(\mathrm{Y}_{2} \mathrm{O}_{3}\right.$ between $\sim 1.24$ and $\left.\sim 1.82 \mathrm{wt} \%\right)$. Core-rim REE patterns (normalized to chondrite values of Mcdonough \& Sun, 1995) within monazites are reported in Figure 6a. Monazites included in pre-tectonic porphyroclasts have a lower content in HREE (Figures 6a and 6b) with respect to the grains located in the main foliation. Monazites in the main foliation have low Eu content (Figure $6 \mathrm{a}$ ). Ages derived from the $\mathrm{U} / \mathrm{Pb}$ and $\mathrm{Th} / \mathrm{Pb}$ systems are generally concordant. Ages from each spot are reported in supporting information (Figure S3) in the compositional map of Y for each grain. The full dataset is in supporting information (Table $\mathrm{S} 2$ ). Th- $\mathrm{Pb}$ ages range from $\sim 333 \pm 5 \mathrm{Ma}$ to $\sim 319 \pm 3 \mathrm{Ma}$ (Figure 6c), while U-Pb ages range from $\sim 329 \pm 13 \mathrm{Ma}$ to $\sim 318 \pm 7 \mathrm{Ma}$ (Figure 6d). Several age groups may be distinguished by considering microstructural position and chemical composition (Figure 6b). Older ages ( 340-330 Ma) were obtained in the low-Y grains included in the porphyroclasts, and no significant age difference is recognized between core and rim of these grains (Figure 6b). Younger ages ( 320-310 Ma) were obtained from the high-Y grains along the main foliation, where a slight difference in age between cores and rims can be recognized (Figure $6 \mathrm{~b}$ ).

\section{Discussion}

\subsection{Structural Framework and Deformation}

In the Emosson Lake and Val Bérard areas interlayered metasedimentary rocks and orthogneiss contain a subvertical NE-SW striking foliation carrying gently NE plunging mineral lineations. Microstructural and crystal fabric kinematic suggest a dextral sense of shear viewed geographically downwards on to the subhorizontal XZ plane. Granitic dikes were injected along the main foliation and subsequently deformed in the Emosson Lake area. 

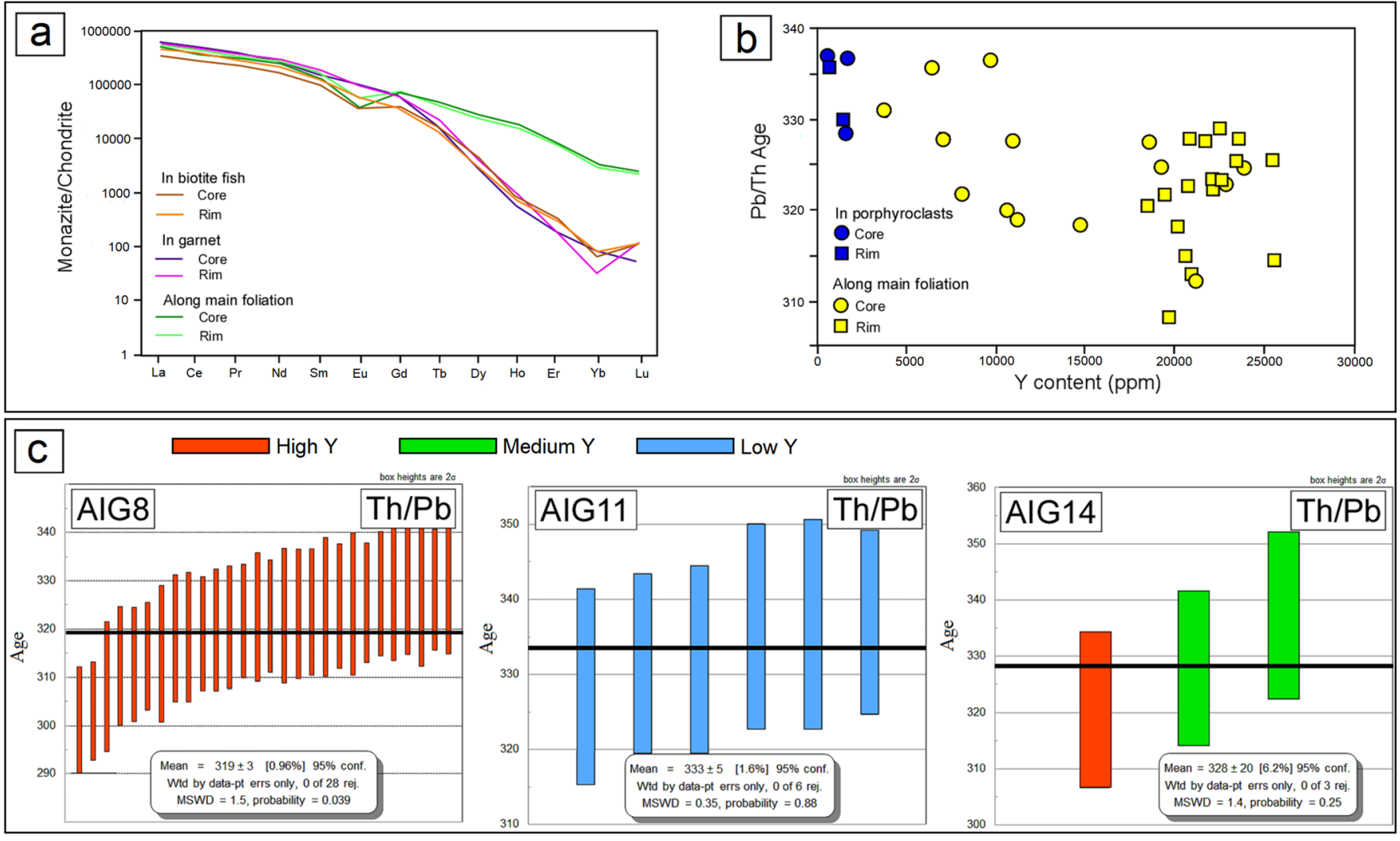

Figure 6. Chemistry of dated monazite crystals. (a) REE distribution; (b) age versus Y content (ppm); (c) average age diagrams for Th-Pb systematic.

In the Emosson Lake area Von Raumer and Bussy (2004) and Genier et al. (2008) described the studied high-strain zone as a mylonitic belt with a thickness of $\sim 500 \mathrm{~m}$ and confined within a migmatitic zone adjacent to the Vallorcine granite, considered as the southeastern limit of the shear zone. Microstructural and quartz c-axis fabric analyses revealed that shear deformation also affects the adjacent non-migmatitic micaschist that previously were not thought to be caught up in this shear deformation (Von Raumer \& Bussy, 2004). However, we detected evidence for shear deformation at up to $\sim 800 \mathrm{~m}$ from the Vallorcine granite. Accordingly, the thickness of the high-strain zone ranges between $800 \mathrm{~m}$ and $650 \mathrm{~m}$ in the two study areas.

The measured quartz c-axis fabrics provide qualitative information on the likely 3-D finite strain within the shear zone. Type-II cross-girdle fabrics and clusters of c-axes around the Y direction indicate almost plain strain under high-temperature conditions (Lister, 1977; Schmid \& Casey, 1986). If the rocks sampled had been deformed in the constrictional field, then the c-axes would define a small circle girdle fabric centered approximately about the lineation. In the case of flattening deformation c-axes would define a small circle girdle centered about the pole to foliation. Furthermore, studied samples are both foliated and lineated in agreement with a deformation close the plain strain.

Kinematic vorticity analyses allow us to define, for the first time, the flow regime of the sheared rocks in the ARM that involves a dominant component of pure shear acting together with simple shear. The estimated percentages of pure shear, obtained with the $\mathrm{C}^{\prime}$ shear band method, range between $51 \%$ and $79 \%$, while the stable porphyroclast method indicates $\sim 60 \%$ pure shear. The topology of the measured quartz fabrics is also indicative of a deformation with a prevalent component of pure shear. Calculated $\theta$ angles range between $20^{\circ}$ and $9^{\circ}$ and combined with the vorticity data indicate a transpressional deformation because the maximum ISA measured in the horizontal plane is oriented at an angle $\theta$ lower than $45^{\circ}$ to the macroscopic shear zone boundary observed in the field. These values indicate a pure shear-dominated transpression because the $\theta$ angle is less than $22.5^{\circ}$ (Fossen, 2016; Tikoff \& Fossen, 1995; Xypolias, 2010). The orthogneisses always record a larger component of pure shear than the metasedimentary rocks, indicating 
a partitioning of deformation between the two lithotypes probably controlled by differences in their rheological properties. Preexisting structural weaknesses are one of the factors that can trigger deformation partition within a shear zone (Jones \& Tanner, 1995).

\subsection{Deformation Temperature}

The syn-kinematic mineral assemblage associated with the mylonitic foliation in the study areas is indicative of amphibolite-facies conditions of metamorphism. In the Emosson Lake area, two superposed mineral assemblages in the metapelites have been described in the literature. Observed garnet zoning indicates early medium-high pressure conditions $\left(8-10 \mathrm{kbar}, 550^{\circ} \mathrm{C}\right)$ followed by decompression and a thermal peak at 46 kbar, 630-650 ${ }^{\circ} \mathrm{C}$ (Von Raumer, 1983; Von Raumer \& Schwander, 1985). In the same area Genier et al. (2008) described a partial melting episode that was synchronous with shearing and occurred at $\mathrm{P}$ and $\mathrm{T}$ conditions close to the vapor-present minimum melting curve for granite (approximately $3.1 \pm 1.1 \mathrm{kbar}$ and $\left.650 \pm 20^{\circ} \mathrm{C}\right)$.

Microstructures in quartz indicate grain boundary migration (GBM) as the dominant recrystallization mechanisms. Chessboard extinction was occasionaly recognized in our samples as an incipient microstructure, but no direct corroborating evidence for high temperature prism [c] slip was recorded in the measured quartz c-axis fabrics. Locally thin section scale microstructural domains characterized by subgrain rotation recrystallization partially overprinting these higher temperature microstructures are present, suggesting that shearing progressively evolved under decreasing ambient temperatures.

Opening angles of the measured quartz c-axis fabrics indicate deformation temperatures ranging between $629^{\circ} \mathrm{C}$ and $556^{\circ} \mathrm{C}$ based on the calibration of Faleiros et al. (2016). These estimated temperatures agree with likely temperature ranges indicated by both the syn-kinematic mineral assemblage and quartz microstructures and are in good agreement with the results of previously published studies in the area (Bussy et al., 2001; Genier et al., 2008; Von Raumer \& Bussy, 2004), suggesting that the measured fabrics were not strongly influenced by any lower temperature overprint. However, because of potential local low temperature overprinting of quartz microstructures, these deformation temperatures are regarded as minimum temperatures.

Quartz microstructures (dominanted by subgrain rotation) in the dikes, injected along the shear zone foliation, suggest relatively low temperature deformation conditions. These dikes are very close to the syn-tectonic Vallorcine granite emplaced at 306.5 \pm 1.5 Ma (Bussy et al., 2000), and even if field relations are not visible in the study area, they could still be related to intrusion of the main granite body. Microstructures in those dikes indicate that deformation was still ongoing under lower temperature conditions during granite intrusion (Von Raumer \& Bussy, 2004).

Greenschist-facies conditions could also represent an Alpine imprint. This could lead to an underestimation of pre-Alpine deformation temperatures. However, the ARM remained at temperatures lower than $320^{\circ} \mathrm{C}$ during Alpine collision (Boutoux et al., 2016) and away from the major Alpine structures. Alpine overprinting was therefore not strong enough to obliterate the older microstructural and crystal fabric indicators for Variscan deformation temperatures. Because of this, the possible presence of an Alpine overprint would have had very little effect on our estimates of Variscan deformation temperatures, strain, and flow vorticity in the study area.

\subsection{Age of the Deformation}

Petrochronology allows us to constrain the age of transpression in the ARM. We recognized two groups of monazites: a first group composed of grains included in garnet or biotite porphyroclasts and a second group composed of grains within the main foliation. The two groups have chemical differences. Grains included in porphyroclasts have a lower content in HREE (heavy rare-earth element) relative to grains in the main foliation. The microstructural positions and chemical compositions reveal that monazite grains of the first group grew before shearing, during prograde metamorphism, while monazite grains of the second group are synkinematic. Monazites in the main foliation have an anomaly in Eu content indicating synchronous growth with feldspar during partial melting (Braden et al., 2017; Rubatto et al., 2013) and suggesting that transpressional deformation occurred either at the same time or shortly after anatexis. Y content is lower in the monazite grains included in porphyroclasts and higher in grains within the foliation, in agreement with the growth of syn-kinematic monazites during retrograde metamorphism and garnet breakdown. Two groups of monazite ages are distinguished. Older ages of $\sim 340-330 \mathrm{Ma}$ are obtained in low-Y grains included in 
porphyroclasts and grown during prograde metamorphism under near peak amphibolite-facies conditions. Younger ages of $\sim 320-310 \mathrm{Ma}$ are obtained from the high-Y grains in the main foliation and represent the onset of transpressional deformation. Older ages agree with the age of $327 \pm 2 \mathrm{Ma}$ (U-Pb on monazite) obtained by Bussy et al. (2000), which is considered to date near peak temperature conditions of amphibolite-facies metamorphism. Because the Vallorcine granite and its dikes are syn-tectonic intrusions emplaced at $306.5 \pm 1.5 \mathrm{Ma}$ (Bussy et al., 2000), we argue that transpressive deformation in the ARM is a long-lasting event of at least $\sim 15 \mathrm{Myr}$.

\subsection{Shear Deformation in the Aiguilles Rouges Massif in the Framework of the Variscan Belt}

The structural evolution and age of deformation in the study areas are very similar to those recognized in the Argentera Massif (Carosi et al., 2016a; Simonetti et al., 2017; Simonetti, Carosi, \& Montomoli, 2018). Here the Ferriere-Mollières Shear Zone (FMSZ), cross-cutting Variscan migmatites, is a steeply dipping dextral transpressional shear zone, with a prevalent pure shear component, active at $320 \mathrm{Ma}$ and developed under decreasing temperature conditions ranging from high amphibolite-facies to greenschist-facies. The age of initiation of the FMSZ was inferred by Simonetti, Carosi, and Montomoli (2018) based on in situ U-Th-Pb dating of syn-kinematic monazites in the high-grade protomylonites. They proposed that the shear zone initiated in an interval between $340 \mathrm{Ma}$ and $330 \mathrm{Ma}$ (ages of asymmetrical high-Y rims in extensional sites of monazite grains along the foliation in the protomylonites) and that exhumation of the lower crust started in the same time interval. Recently, Jouffray et al. (2020) dated at $\sim 339 \mathrm{Ma}\left({ }^{40} \mathrm{Ar} /{ }^{39} \mathrm{Ar}\right.$ on amphiboles) the re-equilibration under amphibolite-facies conditions of eclogites embedded within the migmatites, conferming the interval of $~ 340-330$ Ma for retrogression and initial exhumation of the lower crust of the Argentera Massif, in overall agreement with our findings.

The main difference from the study areas is that, in the FMSZ, vorticity changed in time and space along a deformation gradient, with an increasing simple shear component during later deformation stages (Simonetti, Carosi, \& Montomoli, 2018). However, vorticity analyses from both massifs indicate $\sim 60 \%$ pure shear components at 320 Ma. Vorticity analysis in the Maures Massif of southern France and in northern Sardinia also revealed a very similar deformation regime at this time (Carosi \& Palmeri, 2002; Simonetti et al., 2018). Ages of $320 \mathrm{Ma}$ in the Argentera and Aiguilles Rouges massifs are consistent with ages of transpressional deformation in both the Maures-Tanneron Massif (Cavalaire Fault; Rolland et al., 2009; Schneider et al., 2014; Simonetti, Carosi, Montomoli, Langone, et al., 2018), also in agreement with the study of Oliot et al. (2015), and in northern Sardinia (Carosi et al., 2012; Di Vincenzo et al., 2004; Posada-Asinara Shear Zone), dated at $323 \mathrm{Ma}$ and 320-310 Ma, respectively.

The ECM, the Maures-Tanneron Massif, and the CSB all have a striking similar tectono-metamorphic evolution during Variscan times (Table 1). If the counterclockwise Oligo-Miocenic rotation of the CSB (Advokaat et al., 2014; Todesco \& Vigliotti, 1993) and of the Western Alps (Collombet et al., 2002; Maffione et al., 2008; Thomas et al., 1999) is restored, all these sectors lie in lateral continuity. By adding new structural and geochronological constraints, our new data support and strengthen the model proposed by Rosenbaum et al. (2002), Rollet et al. (2002), and Advokaat et al. (2014) of the CSB being both connected to southern France and in continuity with the Western Alps. Variscan shear deformation along steep belts in Corsica-Sardinia, in the Maures-Tanneron Massif, and in the Argentera Massif has been attributed to motion on a Variscan age continent-scale shear zone, the East Variscan Shear Zone (EVSZ; Carosi et al., 2012; Corsini \& Rolland, 2009; Rolland et al., 2009; Schneider et al., 2014, Simonetti, Carosi, \& Montomoli, 2018, Simonetti, Carosi, Montomoli, Langone, et al., 2018). Our data indicate that the ARM was also part of the EVSZ (Figure 7a).

\subsection{Evolution of the East Variscan Shear Zone}

The EVSZ is not a single shear zone but a network of interconnected transpressive shear zones that developed progressively and record a similar tectono-metamorphic history. Its branches preserved in the various fragments of the belt have nearly the same age, but some of them are slightly older (Figure 7b). This can be explained by their progressive growth using a tectonic linkage model (Fossen \& Cavalcante, 2017; Soliva \& Benedicto, 2004; Trudgill \& Cartwright, 1994; Walsh et al., 2002). Shear zones grow in length as they accumulate displacement and tend to connect with adjacent structures to form composite systems or networks (Figure 8a). The result is that some of the branches were actived earlier than the others (Figure 8b) and 


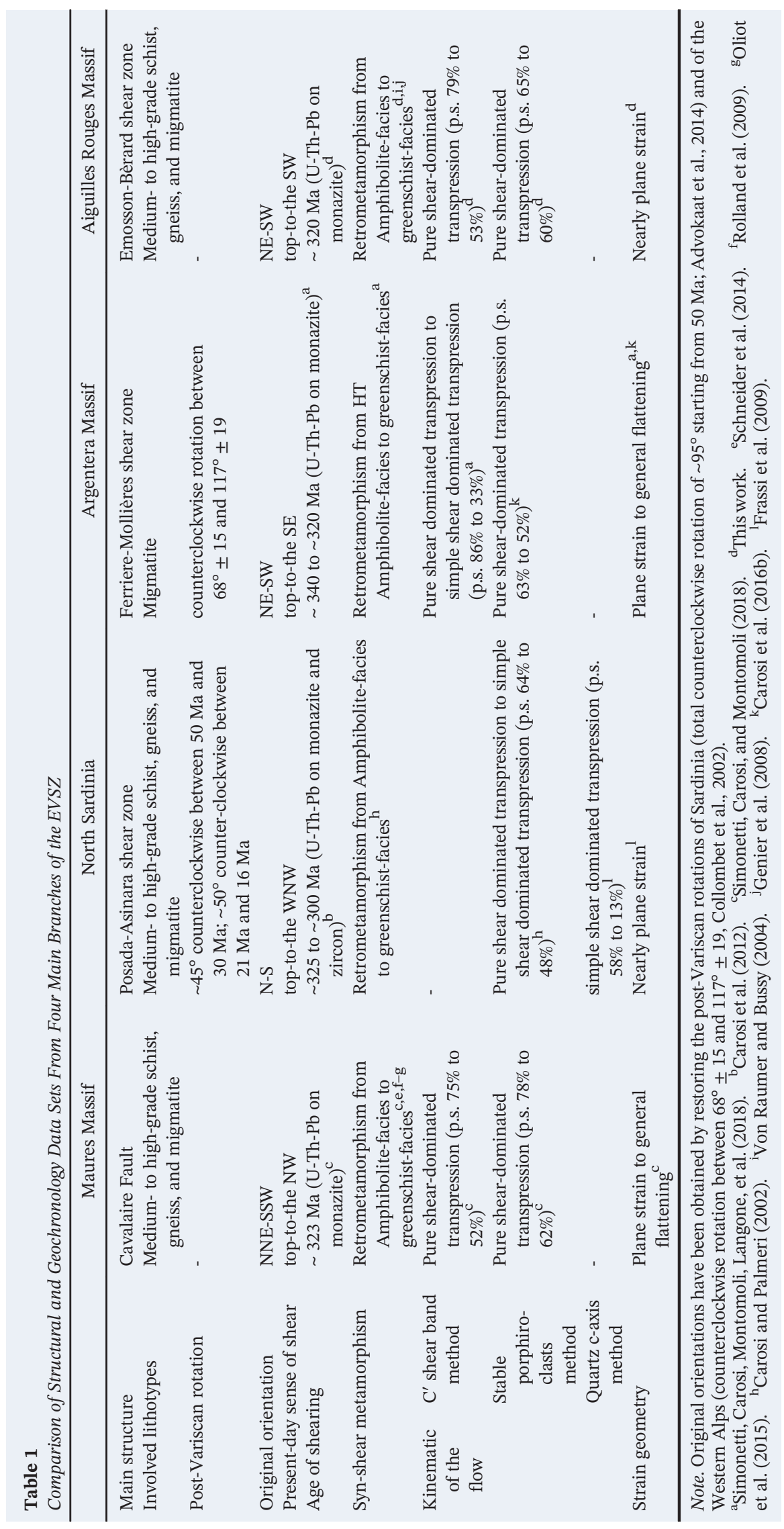




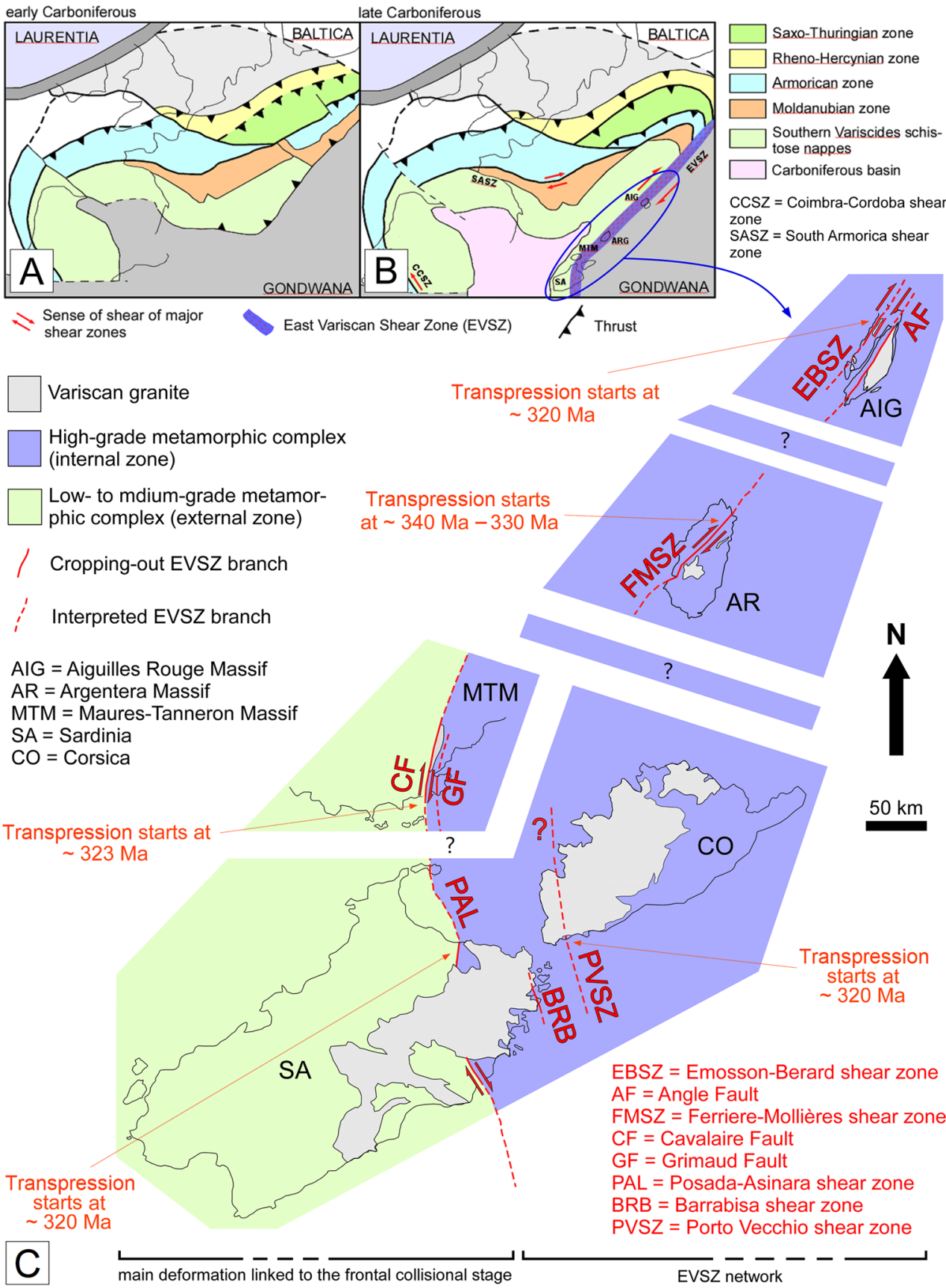

Figure 7. Sketch maps of the Variscides during (a) early Carboniferous (modified after Faure et al., 2005; Guillot \& Ménot, 2009) and (b) late carboniferous (modified after Carosi et al., 2012; Guillot \& Ménot, 2009; Simonetti, Carosi, \& Montomoli, 2018); (c) inferred lateral relationships between the branches of EVSZ.

therefore record a longer deformation history (e.g., the FMSZ in the Argentera Massif). On the other hand, younger branches record a shorter history (i.e., the Posada-Asinara Shear Zone in northern Sardinia). Based on the age of transpression in the different fragments of the EVSZ, we can identify at least two generations of branches: a first generation at around $\sim 340-330 \mathrm{Ma}$ and a second branch at $\sim 320$ Ma. A detailed investigation of other shear zones, potentially linked to the EVSZ, could lead to the recognition of other generations of branches.

It should be noted that the older branches, like the FMSZ (Argentera Massif), but unlike the shear zones in the Maures-Tanneron Massif, Aiguilles Rouges, and northern Sardinia, developed fully within migmatitic 

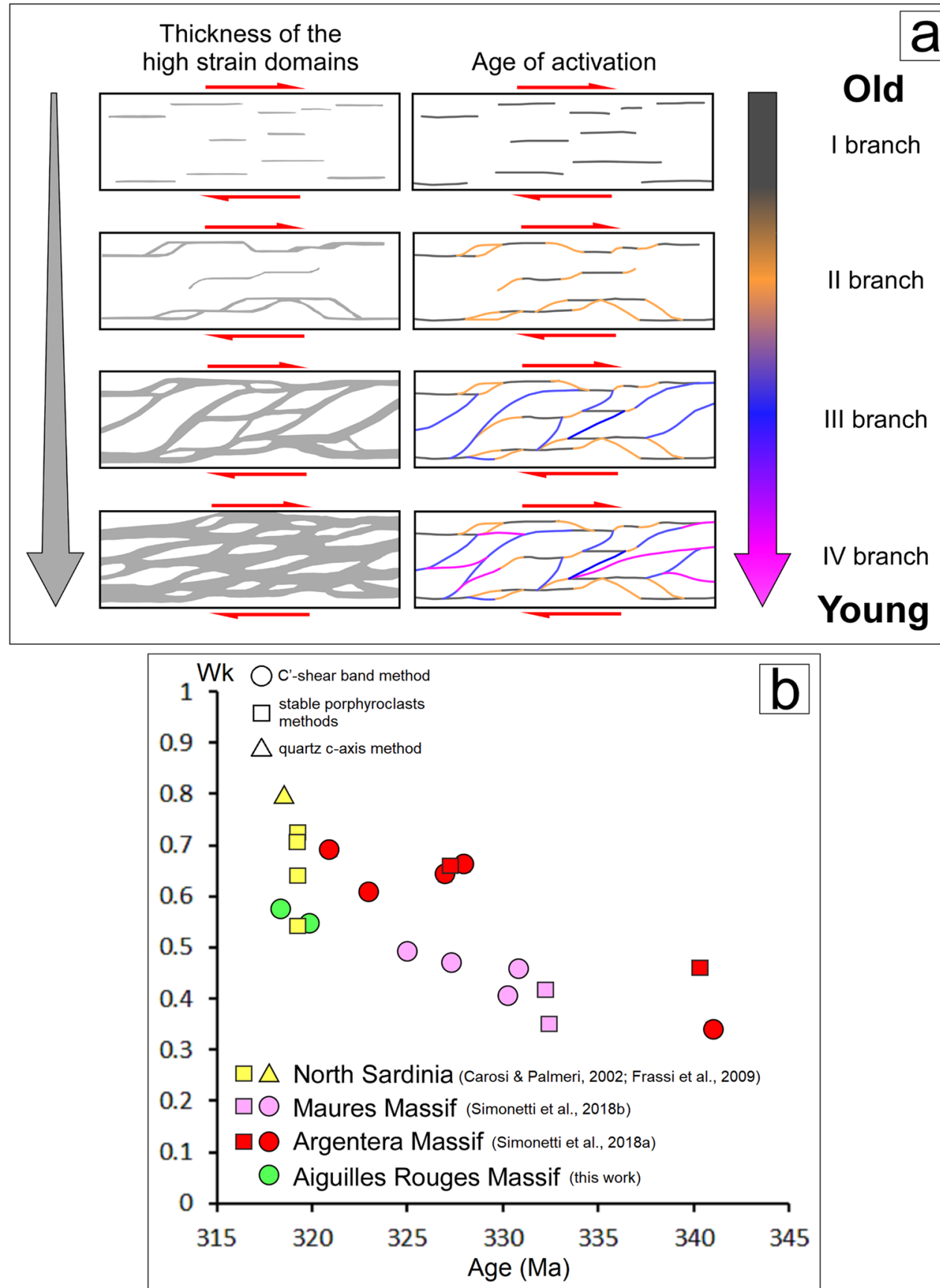

Figure 8. (a) Sketch representing the evolution of a system of dextral shear zones based on the "growth by linkage" model. In the left column is reported the evolution of proportion of high strain domains within the shear zone over time; in the right column the colors represent the age of activation of the shear zone branches; (b) relation between vorticity number and isotopic ages in the Argentera Massif, the Aiguilles Rouges Massif, the Maures Massif, and in northern Sardinia.

crust. Variscan transpression is considered to be synchronous with or to have initiate shortly after anatexis (Genier et al., 2008; Padovano et al., 2014; Rolland et al., 2009; Simonetti, Carosi, \& Montomoli, 2018; Simonetti, Carosi, Montomoli, Langone, et al., 2018). It is therefore possible that transpressional deformation along the EVSZ preferentially started to be accomodated in the lower crust which was easier to deform because of ongoing anatexis and later migrated into the non-migmatitic crust. Melt enhances deformation and strain localization (Kellet et al., 2019; Rosenberg \& Handy, 2005; Weinberg, 2016). Partial melting in the lower crust decreases the resistance of the rocks by nearly 30\% (Barboza \& 
Bergantz, 1998; Diener \& Fagereng, 2014; Misra et al., 2014; Vanderhaeghe \& Teyssier, 2001), and only an $\sim 7 \%$ melt fraction is needed to lower the rock strength by almost an order of magnitude (Rosenberg \& Handy, 2005).

A progressive increase in the simple shear component during transpressional deformation is recognized in the high-strain portions of shear zones in both northern Sardinia (Carosi et al., 2009; Carosi \& Palmeri, 2002; Graziani et al., 2020) and the Argentera Massif (Simonetti, Carosi, \& Montomoli, 2018). In the ARM we did not detect this temporal variation in vorticity of flow, probably because of the spatial partitioning of flow within the shear zone. A general increasing component of simple shear during time, at the scale of the whole EVSZ, can be recognized by comparing vorticity data and ages of the different branches (Figure $8 \mathrm{~b}$ ). This reflects a change in the continent-scale stress field, which could be due to a change in the relative convergence angle between the plates over time or to rotation of the active structures during ongoing collision.

The transpressional deformation regime, the high temperature of deformation, and the late Carboniferous age of shearing in the ECM all suggest that activity on the EVSZ is not related to post-Variscan deformation and a transition from Pangea B to Pangea A. Our study therefore demonstrates, at least in the Variscan fragment of the Western Alps, that there are no geological or structural data that would support the dextral movement of Gondwana in Early Permian time. This agrees with Pohl et al. (2018) who recognized that Carboniferous age transpressive dextral shear zones occur in the external part of the Alps and are unrelated to both Early Permian basin formation and Permian Pangea B to A transformation. Furthermore, shear in the external part of Western Alps predates deposition of the Early Permian rocks that yielded the paleomagnetic data (Muttoni et al., 2003) on which Pangea B is based.

Activation of the older branches of the EVSZ is coeval with the onset of sinistral transpressive deformation in the western sector of the Iberian Massif dated at $340 \mathrm{Ma}$ (U-Th-Pb on monazite and zircon; Pereira et al., 2008, 2010). Transpression in this sector of the Variscan Belt is interpreted to be a consequence of complex polyphasic indentation of a Gondwana promontory (Dias et al., 2016) and to orogenic syntaxial bending (Authemayou et al., 2019). The EVSZ may have contributed to this process during its early stages and subsequently facilitated formation of a second arc that characterizes the eastern sector of the Variscan Belt.

Our data agree with the composite orocline model proposed by Matte (1986a, 1986b, 2001), Corsini and Rolland (2009), Guillot et al. (2009), Carosi et al. (2012), and Simonetti, Carosi, and Montomoli (2018) and confirm that reconstruction models for the European Variscan Belt should consider the presence of an arc limited by the EVSZ located in the eastern part of the belt.

It is likely that the EVSZ also played a primary role as an inherited crustal discontinuity that influenced the evolution of new structures during post-Variscan and Alpine evolution (Ballèvre et al., 2018; Bergomi et al., 2017). Jammes and Lavier (2019), using numerical models, discussed the influence of strength variations from inherited crustal fabrics on the mechanism of rifting during the formation of magma-poor margins. Vertical fabrics favor initial formation of horst-and-graben structures whereas horizontal and shallowly dipping fabrics favor the formation of core complexes.

During Variscan transpressive deformation, the development of vertical fabrics is predominant, and therefore, horst and graben formation would be facilitated during the initial stages of post-Variscan extension and subsequent rifting. The presence of the EVSZ also has implications for the original position and provenance of the crustal blocks subsequently involved in rifting during Pangea break-up and Alpine collision. As pointed out by Ballèvre et al. (2018), the Helvetic Alpine basement was separated from the Penninic Alpine basement by this shear zone during Carboniferous times, and these basement blocks may have had contrasting geological histories during the initial stages of Variscan deformation. The juxtaposition of the basement of these two Alpine domains could have started during late Carboniferous time because of motion on the EVSZ.

\section{Conclusions}

This study demonstrates that the ARM (French Alps) is affected by Variscan dextral pure-shear dominated transpression that started under high-temperature conditions and continued during retrograde metamorphism. Partitioning of pure and simple shear components during deformation has been demonstrated. The transpression commenced at $\sim 320 \mathrm{Ma}$ and continued for nearly $\sim 15$ Myr. Transpressional Variscan 
deformation in the ARM is similar to that recorded in the Argentera Massif (French and Italian Alps), in the Maures Massif (southern France), and in the CSB, as all these sectors were in lateral continuity during Variscan time. This further confirms that these massifs were all part of the same continent-scale dextral shear zone system (the EVSZ). Activity on the EVSZ is related to Carboniferous age transpression and not to post Variscan deformation. The EVSZ had a long-lasting history: It played a primary role during the polyphase indentation of Gondwana, in the shaping of the eastern sector of the Variscan Belt during late Variscan time, and finally as an inherited discontinuity that influenced the post-Variscan and Alpine evolution of western Europe.

A multidisciplinary approach is essential for obtaining useful results from the study of shear zones, especially at the regional scale. Independent analytical methods for constraining the kinematics, temperatures, and absolute timing of deformation should always be systematically applied in different sectors of regional-scale structures in order to obtain data capable of addressing first-order questions on regional/continent-scale tectonics and correlating between now widely separated fragments of once continuous orogenic belts.

\section{Software}

Stable porphyroclasts analyses were performed with EllipseFit 3.2 (Vollmer, 2015). Geochronological data were treated with Isoplot 3.0 (Ludwig, 2003), data reduction were carried out using Iolite 2.5 (Paton et al., 2010).

\section{Acknowledgments}

Research was funded by PRIN 2015 (Carosi and Montomoli) and RILO (60\%, R. Carosi). We thank Andrew Kylander-Clark for assistance with petrochronology analyses. We thank Stéphane Guillot, Paris Xypolias, and an anonymous reviewer for their comments that improved the he manuscript. Taylor Schildgen is acknowledged for editorial work. Data are archived at https://doi.org/ 10.17632/r3jpmcpvy5.1 (Simonetti, 2020).

\section{References}

Advokaat, E. L., van Hinsbergen, D. J. J., Maffione, M., Langereis, C. G., Vissers, R. L. M., Cherchi, A., et al. (2014). Eocene rotation of Sardinia, and the paleogeography of the western Mediterranean region. Earth and Planetary Science Letters, 401, 183-195. https://doi. org/10.1016/j.epsl.2014.06.012

Aleinikoff, J. N., Schenck, W. S., Plank, M. O., Srogi, L., Fanning, C. M., Kamo, S. L., \& Bosbyshell, H. (2006). Deciphering igneous and metamorphic evens in high-grade rocks of the Wilmington Complex, Delaware: Morphology, cathodoluminescence and backscattered electron zoning, and SHRIMP U-Pb geochronology of zircon and monazite. Geological Society of America Bulletin, 118, 39-64. https:// doi.org/10.1130/B25659.1

Amelin, Y., \& Zaitsev, A. N. (2002). Precise geochronology of phoscorites and carbonatites: The critical role of U-series disequilibrium in age interpretations. Geochimica et Cosmochimica Acta, 66, 2399-2419.

Arthaud, F., \& Matte, P. (1977). Late Paleozoic strikeslip faulting in southern Europe and northern Africa; result of a right-lateral shear zone between the Appalachians and the Urals. Geological Society of America Bulletin, 88, 1305-1320.

Authemayou, C., le Gall, B., Caroff, M., \& Grosjean, D. B. (2019). Wrench-related dome formation and subsequent orogenic syntax bending in a hot orogen (Variscan Ibero-Armorican Arc, the Ouessant Island, France). Tectonics, 38, 3563-3585. https://doi.org/10.1029/ 2018TC005189

Bajolet, F., Replumaz, A., \& Lainé, R. (2013). Orocline and syntaxes formation during subduction and collision: Orocline syntaxes in convergent settings. Tectonics, 32, 1529-1546. https://doi.org/10.1002/tect.20087

Ballèvre, M., Manzotti, P., \& Dal Piaz, G. V. (2018). Pre-Alpine (Variscan) inheritance: A key for the location of the future Valaisan Basin (Western Alps).: Pre-Alpine (Variscan) inheritance: A key for the location of the future Valaisan Basin (Western Alps). Tectonics, 37, 786-817. https://doi.org/10.1002/2017TC004633

Barboza, S. A., \& Bergantz, G. W. (1998). Rheological transitions and the progress of melting of crustal rocks. Earth and Planetary Science Letters, 158, 19-29.

Bellot, J. P. (2005). The Palaeozoic evolution of the Maures massif (France) and its potential correlation with other areas of the Variscan belt: A review. Journal of the Virtual Explorer, 19, 4. https://doi.org/10.3809/jvirtex.2005.00116

Bergomi, M. A., Dal Piaz, G. V., Malusà, G. M., Monopoli, B., \& Tunesi, A. (2017). The Grand St Bernard-Briançonnais nappe system and the Paleozoic inheritance of the Western Alps unravelled by zircon U-Pb dating. Tectonics, 36, 2950-2972. https://doi.org/10.1002/ 2017TC004621

Boutoux, A., Bellahsen, N., Nanni, U., Pik, R., Verlaguet, A., Rolland, Y., \& Lacombe, O. (2016). Thermal and structural evolution of the external Western Alps: Insights from (U-Th-Sm)/He thermochronology and RSCM thermometry in the Aiguilles Rouges/Mont Blanc massifs. Tectonophysics, 683, 109-123.

Braden, Z., Godin, L., \& Cottle, J. M. (2017). Segmentation and rejuvenation of the Greater Himalayan sequence in western Nepal revealed by in situ $\mathrm{U}-\mathrm{Th} / \mathrm{Pb}$ monazite petrochronology. Lithos, 285, 751-765.

Brun, J. P., \& Burg, J. P. (1982). Combined thrusting and wrenching in the Ibero-Armorican arc: A corner effect during continental collision. Earth and Planetary Science Letters, 61, 319-332.

Buick, I. S., Hermann, J., Williams, I. S., Gibson, R. L., \& Rubatto, D. (2006). A SHRIMP U-Pb and LA-ICP-MS trace element study of the petrogenesis of garnet-cordierite-orthoamphibole gneisses from the Central Zone of the Limpopo Belt, South Africa. Lithos, 88, $150-172$.

Burg, J. P., \& Matte, P. (1978). A cross section through the French Massif Central and the scope of its Variscan Geodynamic Evolution. Zeitschrift der Deutschen Geologischen Gesellschaft, 129, 429-460.

Bussy, F., Hernandez, J., \& Von Raumer, J. (2000). Bimodal magmatism as a consequence of the post-collisional readjustment of the thickened Variscan continental lithosphere (Aiguilles Rouges-Mont Blanc Massifs, Western Alps). Transactions of the Royal Society of Edinburgh. Earth Science, 91, 221-233. https://doi.org/10.1017/S0263593300007392

Bussy, F., von Raumer, J. F., \& Capuzzo, N. (2001). Mont Blanc -Aiguilles Rouges Massifs - (external massifs). In G.M. Stampfli (ed.): Geology of the western Swiss Alps, a guidebook. Field-Trip 1. Mémoires de Géologie (Lausanne), 36, 53-85. 
Capuzzo, N., \& Bussy, F. (2001). Syn-sedimentary volcanism in the Late Carboniferous Salvan-Donrénaz basin (Western Alps). Memorie Scienze Naturali Brescia, 25, 203-211.

Capuzzo, N., Handler, R., Neubauer, F., \& Wetzel, A. (2003). Post-collisional rapid exhumation and erosion during continental sedimentation: The example of the late Variscan Salvan-Dorénaz basin (Western Alps). International Journal of Earth Sciences, 92 , 364-379.

Carey, S. W. (1955). The orocline concept in geotectonics. Papers and Proceedings of the Royal Society of Tasmania, 89, 255-288.

Carosi, R., D'Addario, E., Mammoliti, E., Montomoli, C., \& Simonetti, M. (2016a). Geology of the northwestern portion of the Ferriere-Mollieres Shear Zone, Argentera Massif, Italy. Journal of Maps, 12, 466-475. https://doi.org/10.1080/17445647.2016.1243491

Carosi, R., D'Addario, E., Mammoliti, E., Montomoli, C., \& Simonetti, M. (2016b). Vorticty of the flow and strain analysis in the Argentera Massif (External Crystalline Massifs, Western Alps): Recognition of a regional pure-shear dominated transpression. Rend. Online Soc. Geol. It. Suppl, 1, 40.

Carosi, R., Frassi, C., \& Montomoli, C. (2009). Deformation during exhumation of medium- and high-grade metamorphic rocks in the Variscan chain in northern Sardinia (Italy). Geological Journal, 44, 280-305.

Carosi, R., Montomoli, C., Tiepolo, M., \& Frassi, C. (2012). Geochronological constraints on post-collisional shear zones in the Variscides of Sardinia (Italy): Post-collisional shear zones in the Variscides of Sardinia. Terra Nova, 24, 42-51. https://doi.org/10.1111/j.13653121.2011.01035.x

Carosi, R., \& Palmeri, R. (2002). Orogen-parallel tectonic transport in the Variscan belt of northeastern Sardinia (Italy): Implications for the exhumation of medium-pressure metamorphic rocks. Geological Magazine, 139, 497-511. https://doi.org/10.1017/S0016756802006763

Collombet, M., Thomas, J. C., Chauvin, A., Tricart, P., Bouillin, J. P., \& Gratier, J. P. (2002). Counterclockwise rotation of the western Alps since the Oligocene: New insights from paleomagnetic data. Tectonics, 21(4), 1032. https://doi.org/10.1029/2001TC901016

Compagnoni, R., Ferrando, S., Lombardo, B., Radulesco, N., \& Rubatto, D. (2010). Paleo-European crust of the Italian Western Alps: Geological history of the Argentera Massif and comparison with Mont Blanc-Aiguilles Rouges and Maures-Tanneron Massifs. Journal of the Virtual Explorer, 36, 4. https://doi.org/10.3809/jvirtex.2010.00228

Corsini, M., \& Rolland, Y. (2009). Late evolution of the Southern European Variscan Belt: Exhumation of the lower crust in a context of oblique convergence. Comptes Rendus Geoscience, 341, 214-223. https://doi.org/10.1016/j.crte.2008.12.002

Davy, P., \& Cobbold, P. R. (1988). Indentation tectonic in nature and experiment. 1. Experiments scaled for gravity. Bullettin of the Geological Insititutions of Uppsala, 14, 129-141.

Di Vincenzo, G., Carosi, R., \& Palmeri, R. (2004). The relationship between tectono-metamorphic evolution and argon isotope records in white mica: Constraints from in situ ${ }^{40} \mathrm{Ar}-{ }^{39} \mathrm{Ar}$ laser analysis of the Variscan basement of Sardinia. Journal of Petrology, 45, $1013-1043$. https://doi.org/10.1093/petrology/egh002

Dias, R., \& Ribeiro, A. (1995). The Ibero-Armorican Arc: A collision effect against an irregular continent? Tectonophysics, 246, 113-128.

Dias, R., Ribeiro, A., Romão, J., Coke, C., \& Moreira, N. (2016). A review of the arcuate structures in the Iberian Variscides; constraints and genetic models. Tectonophysics, 681, 170-194. https://doi.org/10.1016/j.tecto.2016.04.011

Diener, J. F. A., \& Fagereng, Å. (2014). The influence of melting and melt drainage on crustal rheology during orogenesis. Journal of Geophysical Research: Solid Earth, 119, 6193-6210. https://doi.org/10.1002/2014JB011088

Dobmeier, C. (1998). Variscan P-T deformation paths from the southwestern Aiguilles Rouges Massif (external massif, western Alps) and their implication for its tectonic evolution. Geologische Rundschau, 87, 107-123.

Dobmeier, C., \& von Raumer, J. F. (1995). Significance of latest-Variscan and Alpine deformation for the evolution of Montagne de Pormenaz (Southwestern Aiguilles Rouges Massif, Western Alps). Eclogae Geologicae Helvetiae, 88, 267-279.

Engi, M., Lanari, P., \& Kohn, M. J. (2017). Significant Ages-An introduction to petrochronology: methods and applications. In M. Engi, P. Lanari, \& M. J. Kohn (Eds.), Petrocronology: Methods and applications. Reviews in Mineralogy and Geochemistry (Vol. 83, pp. 1-12). Chantilly, Virginia, USA: Mineralogical Society of America and the Geochemical Society. https://doi.org/10.1515/9783110561890-002

Epard, J. L. (1990). La Nappe de Morcles au sud-ouest du Mont-Blanc. Mémoires de Geologie (Lausanne), 8, 1-152.

Faleiros, F. M., Moraes, R., Pavana, M., \& Campanha, G. A. C. (2016). A new empirical calibration of the quartz c-axis fabric opening-angle deformation thermometer. Tectonophysics, 671, 173-182.

Faure, M., Bé Mézème, E., Duguet, M., Cartier, C., \& Talbot, J. (2005). Paleozoic tectonic evolution of medio-Europa from the example of the French Massif Central and Massif Armoricain. In: Carosi, R., Dias, R., Iacopini, D., \& Rosenbaum, G. (Eds.), The southern Variscan belt. Journal of the Virtual Explorer, 19(5). https://doi.org/10.3809/jvirtex.2005.00120

Fernández-Lozano, J., Pastor-Galán, D., Gutiérrez-Alonso, G., \& Franco, P. (2016). New kinematic constraints on the Cantabrian orocline: A paleomagnetic study from the Peñalba and Truchas synclines, NW Spain. Tectonophysics, 681, 195-208. https://doi.org/10.1016/j. tecto.2016.02.019

Fossen, H. (2016). Structural geology (p. 524). Cambridge, New York: Cambridge University Press.

Fossen, H., Basil, T., \& Christian, T. (1994). Strain modeling of transpressional and transtensional deformation. Norsk Geologisk Tidsskrift, 74, 134-145.

Fossen, H., \& Cavalcante, G. C. G. (2017). Shear zones-A review. Earth-Science Reviews, 171, 434-455. https://doi.org/10.1016/j. earscirev.2017.05.002

Fossen, H., \& Tikoff, B. (1993). The deformation matrix for simultaneous simple shearing, pure shearing and volume change, and its application to transpression-transtension tectonics. Journal of Structural Geology, 15, 413-422. https://doi.org/10.1016/01918141(93)90137-Y

Foster, G., Gibson, H. D., Parrish, R., Horstwood, M., Fraser, J., \& Tindle, A. (2002). Textural, chemical and isotopic insights into the nature and behaviour of metamorphic monazite. Chemical Geology, 191, 183-207.

Frassi, C., Carosi, R., Montomoli, C., \& Law, R. D. (2009). Kinematics and vorticity of flow associated with post-collisional oblique transpression in the Variscan Inner Zone of northern Sardinia (Italy). Journal of Structural Geology, 31, 1458-1471.

García-Navarro, E., \& Fernández, C. (2004). Final stages of the Variscan orogeny at the southern Iberian massif: Lateral extrusion and rotation of continental blocks: Variscan escape tectonics, SW Iberia. Tectonics, 23, TC001. https://doi.org/10.1029/2004TC001646

Genier, F., Bussy, F., Epard, J. L., \& Baumgartner, L. (2008). Water-assisted migmatization of metagraywackes in a Variscan shear zone, Aiguilles-Rouges massif, western Alps. Lithos, 102, 575-597. https://doi.org/10.1016/j.lithos.2007.07.024

Gillam, B. G., Little, T. A., Smith, E., \& Toy, V. G. (2013). Extensional shear band development on the outer margin of the Alpine mylonite zone, Tatare Stream, Southern Alps, New Zealand. Journal of Structural Geology, 54, 1-20. https://doi.org/10.1016/j.jsg.2013. 06.010

Glen, R., \& Roberts, J. (2012). Formation of oroclines in the New England Orogen, Eastern Australia. In: Johnston, S., \& Rosenbaum, G. (Eds.), Oroclines. Journal of the Virtual Explorer, Electronic Edition, ISSN 1441-8142, (3), 43. https://doi.org/10.3809/jvirtex.2012.00305 
Graziani, R., Montomoli, C., Iaccarino, S., Menegon, L., Nania, L., \& Carosi, R. (2020). Structural setting of a transpressive shear zone: Insights from geological mapping, quartz petrofabric and kinematic vorticity analysis in NE Sardinia (Italy). Geological Magazine, 1-19. https://doi.org/10.1017//S0016756820000138

Guillot, S., Di Paola, S., Ménot, R. P., Ledru, P., Spalla, M. I., Gosso, G., \& Schwartz, S. (2009). Suture zones and importance of strike-slip faulting for Variscan geodynamic reconstructions of the External Crystalline Massifs of the western Alps. Bulletin de la Société géologique de France, 180, 483-500. https://doi.org/10.2113/gssgfbull.180.6.483

Guillot, S., \& Ménot, R. P. (2009). Paleozoic evolution of the External Crystalline Massifs of the Western Alps. Comptes Rendus Geoscience, $341,253-265$.

Hermann, J., \& Rubatto, D. (2003). Relating zircon and monazite domains to garnet growth zones: Age and duration of granulite facies metamorphism in the Val Malenco lower crust. Journal of Metamorphic Geology, 21, 833-852.

Horstwood, M. S. A., Foster, G. L., Parrish, R. R., Noble, S. R., \& Nowell, G. M. (2003). Common-Pb corrected in-situ U-Pb accessory mineral geochronology by LA-MC-ICP-MS. Journal of Analytical Atomic Spectrometry, 18(8), 837-846. https://doi.org/10.1039/b304365g

Iaccarino, S., Montomoli, C., Carosi, R., Montemagni, C., Massonne, H. J., Langone, A., et al. (2017). Pressure-temperature-deformationtime constraints on the South Tibetan Detachment System in the Garhwal Himalaya (NW India). Tectonics, 36, 2281-2304. https://doi. org/10.1002/2017TC004566

Iacopini, D., Frassi, C., Carosi, R., \& Montomoli, C. (2011). Biases in three-dimensional vorticity analysis using porphyroclast system: Limits and application to natural examples. Geological Society, London, Special Publications, 360, 301-318. https://doi.org/10.1144/ SP360.17

Jaffey, A. H., Flynn, K. F., Glendenin, L. E., Bentley, C. R., \& Essling, A. M. (1971). Precision measurements of half-lives and specific activities of ${ }^{235} \mathrm{U}$ and ${ }^{238} \mathrm{U}$. Physical Review C, 4, 1889-1906. https://doi.org/10.1103/PhysRevC.4.1889

Jammes, S., \& Lavier, L. L. (2019). Effect of contrasting strength from inherited crustal fabrics on the development of rifting margins. Geosphere, 15(2), 1-16. https://doi.org/10.1130/GES01686.1

Jeffery, G. (1922). The motion of ellipsoidal particles immersed in a viscous fluid. Proceedings of the Royal Society of London, A122, 161-179.

Johnston, S. T., Weil, A. B., \& Gutiérrez-Alonso, G. (2013). Oroclines: Thick and thin. Geological Society of America Bulletin, 125, 643-663.

Jones, R. R., \& Tanner, G. P. W. (1995). Strain partitioning in transpression zones. Journal of Structural Geology, 17, 793-802. https://doi org/10.1016/0191-8141(94)00102-6

Jouffray, F., Spalla, M. I., Lardeaux, J. M., Filippi, M., Rebay, G., Corsini, M., et al. (2020). Variscan eclogites from the ArgenteraMercantour Massif (External Crystalline Massifs, SW Alps): A dismembered cryptic suture zone. International Journal of Earth Sciences, 1-22. https://doi.org/10.1007/s00531-020-01848-2

Kellet, D. A., Cottle, J. M., \& Larson, K. P. (2019). The South Tibetan Detachment System: History, advances, definition and future directions. Geological Society, London, Special Publications, 483, 377-400. https://doi.org/10.1144/SP483.2

Kerrich, R., Allison, I., Barnett, R. L., Moss, S., \& Starkey, J. (1980). Microstructural and chemical transformations accompanying deformation of a granite in a shear zone at Mie'ville, Switzerland; with implications for stress corrosion cracking and superplastic flow. Contributions to Mineralogy and Petrology, 73, 221-242.

Kretz, R. (1983). Symbols for rock-forming minerals. American Mineralogist, 68, 277-279.

Kroner, U., \& Romer, R. L. (2009). The Saxo-Thuringian Zone-Tip of the Armorican Spur and part of the Gondwana plate. In U. Linnemann, \& R. L. Romer (Eds.), Pre-Mesozoic geology of Saxo-Thuringia-From the Cadomian active margin to the Variscan Orogen, (pp. 371-394). Stuttgart: Schweizerbart.

Kroner, U., \& Romer, R. L. (2013). Two plates-Many subduction zones: The Variscan orogeny reconsidered. Gondwana Research, 24, 298-329. https://doi.org/10.1016/j.gr.2013.03.001

Kruhl, J. H. (1998). Reply: Prism- and basal-plane parallel subgrain boundaries in quartz: A microstructural geothermobarometer. $s$, 16, 142-146. https://doi.org/10.1046/j.1525-1314.1996.00413.x

Kurz, G. A., \& Northrup, C. J. (2008). Structural analysis of mylonitic rocks in the Cougar Creek Complex, Oregon-Idaho using the porphyroclast hyperbolic distribution method, and potential use of SC'-type extensional shear bands as quantitative vorticity indicators. Journal of Structural Geology, 30, 1005-1012. https://doi.org/10.1016/j.jsg.2008.04.003

Kylander-Clark, A., Hacker, B., \& Cottle, J. M. (2013). Laser ablation split-stream ICP petrochronology. Chemical Geology, 345, 99-112. https://doi.org/10.1016/j.chemgeo.2013.02.019

Law, R. D. (1990). Crystallographic fabrics: A selective review of their applications to research in structural geology. Geological Society, London, Special Publications, 54, 335-352. https://doi.org/10.1144/GSL.SP.1990.054.01.30

Law, R. D. (2014). Deformation thermometry based on quartz c-axis fabrics and recrystallization regimes: A review. Journal of Structural Geology, 33, 129-161. https://doi.org/10.1016/j.jsg.2014.05.023

Li, P., \& Rosenbaum, G. (2014). Does the Manning Orocline exist? New structural evidence from the inner hinge of the Manning Orocline (eastern Australia). Gondwana Research, 25, 1599-1613. https://doi.org/10.1016/j.gr.2013.06.010

Li, P., Rosenbaum, G., \& Donchak, P. J. T. (2012). Structural evolution of the Texas Orocline, eastern Australia. Gondwana Research, 22, 279-289. https://doi.org/10.1016/j.gr.2011.09.009

Lister, G. S. (1977). Crossed-girdle c-axis fabrics in quartzites plastically deformed by plane strain and progressive simple shear. Tectonophysics, 39, 51-54. https://doi.org/10.1016/0040-1951(77)90087-7

Lister, G. S., \& Dornisiepen, U. F. (1982). Fabric transitions in the Saxony granulite terrain. Journal of Structural Geology, 4, 81-92. https:// doi.org/10.1016/0191-8141(82)90009-8

Lister, G. S., \& Hobbs, B. E. (1980). The simulation of fabric development during plastic deformation and its application to quartzite: The influence of deformation history. Journal of Structural Geology, 2, 355-370. https://doi.org/10.1016/0191-8141(80)90023-1

Ludwig, K. R. (2003). ISOPLOT 3.00: A geochronological toolkit for micrososft excel. Berkley Geocronology center, Berkely California.

Maffione, M., Speranza, F., Faccenna, C., Cascella, A., Vignaroli, G., \& Sagnotti, L. (2008). A synchronous Alpine and Corsica-Sardinia rotation. Journal of Geophysical Research, 113, B03104. https://doi.org/10.1029/2007JB005214

Matte, P. (1986a). Tectonics and plate tectonics model for the Variscan belt of Europe. Tectonophysics, 126, 329-374.

Matte, P. (1986b). La Chaîne varisque parmi les chaînes paléozoïques péri-atlantiques, modèle d'évolution et position des grands blocs continentaux au Permo-Carbonifère. Bulletin de la Société géologique de France, 8, 4-24.

Matte, P. (2001). The Variscan collage and orogeny (480-290 Ma) and the tectonic definition of the Armorica microplate: A review. Terra Nova, 13, 122-128.

Matte, P., \& Ribeiro, A. (1975). Forme et orientation de l'ellipsoïde de déformation dans la virgation hercynienne de Galice. Relations avec le plissement et hypothèses sur la genèse de l'arc ibéro-armoricain. Comptes Rendus. Académie des Sciences, 280, 2825-2828.

Mcdonough, W. F., \& Sun, S. S. (1995). The composition of the Earth. Chemical Geology, 120, 223-253. 
Mckinney, S. T., Cottle, J. M., \& Lederer, G. W. (2015). Evaluating rare earth element (REE) mineralization mechanisms in Proterozoic gneiss, Music Valley, California. Geological Society of America Bulletin, 127, 1135-1152.

Misra, S., Burg, J.-P., Vigneresse, J.-L., \& Mainprice, D. (2014). Rheological transition during large strain deformation of melting and crystallizing metapelites: Melting and crystallizing rock rheology. Journal of Geophysical Research: Solid Earth, 119, 3971-3985. https:// doi.org/10.1002/2013JB010777

Montomoli, C., Iaccarino, S., Carosi, R., Langone, A., \& Visonà, D. (2013). Tectonometamorphic discontinuities within the Greater Himalayan Sequence in Western Nepal (Central Himalaya): Insights on the exhumation of crystalline rocks. Tectonophysics, 608, 1349-1370. https://doi.org/10.1016/j.tecto.2013.06.006

Mulchrone, K. F. (2007a). An analytical solution in 2D for the motion of rigid elliptical particles with a slipping interface under a general deformation. Journal of Structural Geology, 29, 950-960. https://doi.org/10.1016/j.jsg.2007.03.008

Mulchrone, K. F. (2007b). Shape fabrics in populations of rigid objects in 2D: Estimating finite strain and vorticity. Journal of Structural Geology, 29, 1558-1570. https://doi.org/10.1016/j.jsg.2007.06.006

Muttoni, G., Gaetani, M., Kent, D. V., Sciunnach, D., Angiolini, L., Berra, F., et al. (2009). Opening of the Neo-Tethys Ocean and the Pangea B to Pangea A transformation during the Permian. GeoArabia, 14, 17-48.

Muttoni, G., Kent, D. V., \& Channell, J. E. T. (1996). Evolution of Pangea: Paleomagnetic constraints from the Southern Alps, Italy. Earth and Planetary Science Letters, 140, 97-112.

Muttoni, G., Kent, D. V., Garzanti, E., Brack, P., Abrahamsen, N., \& Gaetani, M. (2003). Early Permian Pangea "B” to Late Permian Pangea “A”. Earth and Planetary Science Letters, 215, 379-394. https://doi.org/10.1016/S0012-821X(03)00452-7

Oliot, E., Melleton, J., Schneider, J., Corsini, M., Gardien, V., \& Rolland, Y. (2015). Variscan crustal thickening in the Maures-Tanneron massif (South Variscan belt, France): New in situ monazite U-Th-Pb chemical dating of high-grade rocks. Bulletin de la Société géologique de France, 186, 145-169.

Padovano, M., Dörr, W., Elter, F. M., \& Gerdes, A. (2014). The East Variscan Shear Zone: Geochronological constraints from the Capo Ferro area (NE Sardinia, Italy). Lithos, 196-197, 27-41. https://doi.org/10.1016/j.lithos.2014.01.015

Padovano, M., Elter, F. M., Pandeli, E., \& Franceschelli, M. (2012). The East Variscan Shear Zone: New insights into its role in the Late Carboniferous collision in southern Europe. International Geology Review, 54, 957-970. https://doi.org/10.1080/00206814.2011.626120

Passchier, C. W. (1987). Stable position of rigid objects in non-coaxial flow: A study in vorticity analysis. Journal of Structural Geology, 9 , 679-690.

Pastor-Galán, D., Groenewegen, T., Brouwer, D., Krijgsman, W., \& Dekkers, M. J. (2015). One or two oroclines in the Variscan orogen of Iberia? Implications for Pangea amalgamation. Geology, 43, 527-530. https://doi.org/10.1130/G36701.1

Pastor-Galán, D., Gutiérrez-Alonso, G., Weil, A., Fernández-Suárez, J., Johnston, S., \& Murphy, J. (2012). A virtual tour of the Ibero-Armorican orocline. In: Johnston S., \& Rosenbaum G. (Eds.), Oroclines. Journal of the Virtual Explorer, Electronic Edition, ISSN 1441-8142, 43(2). https://doi.org/10.3809/jvirtex.2011.00292

Pastor-Galán, D., Ursem, B., Meere, P. A., \& Langereis, C. (2015). Extending the Cantabrian Orocline to two continents (from Gondwana to Laurussia). Paleomagnetism from South Ireland. Earth and Planetary Science Letters, 432, 223-231. https://doi.org/10.1016/j. epsl.2015.10.019

Paton, C., Woodhead, J. D., Hellstrom, J. C., Hergt, J. M., Greig, A., \& Maas, R. (2010). Improved laser ablation U-Pb zircon geochronology through robust downhole fractionation correction. Geochemistry, Geophysics, Geosystems, 11, Q0AA06. https://doi.org/10.1029/ 2009GC002618

Pereira, M. F., Apraiz, A., Silva, J. B., \& Chichorro, M. (2008). Tectonothermal analysis of high-temperature mylonitization in the CoimbraCórdoba shear zone (SW Iberian Massif, Ouguela tectonic unit, Portugal): Evidence of intra-continental transcurrent transport during the amalgamation of Pangea. Tectonophysics, 461, 378-394. https://doi.org/10.1016/j.tecto.2007.11.042

Pereira, M. F., Silva, J. B., Drost, K., Chichorro, M., \& Apraiz, A. (2010). Relative timing of transcurrent displacements in northern Gondwana: U-Pb laser ablation ICP-MS zircon and monazite geochronology of gneisses and sheared granites from the western Iberian Massif (Portugal). Gondwana Research, 17, 461-481. https://doi.org/10.1016/j.gr.2009.08.006

Pilloud, C. (1991). Structures de dèformation alpine dans le synclinal de permo-carbonifère de Salvan-Dorenaz (massif de Aiguilles Rouges). Memoires de Géologie (Lausanne), 9, 1-100.

Platt, J. P., \& Vissers, R. L. M. (1980). Extensional structures in anisotropic rocks. Journal of Structural Geology, 2, 397-410. https://doi.org/ 10.1016/0191-8141(80)90002-4

Pohl, F., Froitzheim, N., Obermüller, G., Tomaschek, F., Schroder, O., Nagel, J. Y., et al. (2018). Kinematics and age of syn-intrusive detachment faulting in the Southern Alps: Evidence for Early Permian crustal extension and implications for the Pangea A versus B Controversy. Tectonics, 37, 3668-3689. https://doi.org/10.1029/2018TC004974

Pyle, J. M., \& Spear, F. S. (1999). Yttrium zoning in garnet: Coupling of major and accessory phases during metamorphic reactions. Geological Materials Research, 1, 1-49.

Pyle, J. M., Spear, F. S., Rudnick, R. L., \& McDonough, W. F. (2001). Monazite-xenotime-garnet equilibrium in metapelites and a new monazite-garnet thermometer. Journal of Petrology, 42, 2083-2107.

Rolland, Y., Corsini, M., \& Demoux, A. (2009). Metamorphic and structural evolution of the Maures-Tanneron massif (SE Variscan chain): Evidence of doming along the transpressional margin. Bulletin de la Société géologique de France, special paper, 180, 217-230.

Rolland, Y., Cox, S., Boullier, A. M., Pennacchioni, G., \& Mancktelow, N. (2003). Rare earth and trace element mobility in mid-crustal shear zones: Insights from the Mont Blanc Massif (Western Alps). Earth and Planetary Science Letters, 214(1-2), 203-219.

Rollet, N., Déverchère, J., Beslier, M.-O., Guennoc, P., Réhault, J. P., Sosson, M., \& Truffert, C. (2002). Back arc extension, tectonic inheritance, and volcanism in the Ligurian Sea, Western Mediterranean: Ligurian Sea back arc structure and evolution. Tectonics, 21(3), 1015. https://doi.org/10.1029/2001TC900027

Rosenbaum, G., Lister, G. S., \& Duboz, C. (2002). Reconstruction of the tectonic evolution of the western Mediterranean since the Oligocene. Journal of the Virtual Explorer, 8. https://doi.org/10.3809/jvirtex.2002.00053

Rosenberg, C. L., \& Handy, M. R. (2005). Experimental deformation of partially melted granite revisited: Implications for the continental crust. Journal of Metamorphic Geology, 23, 19-28. https://doi.org/10.1111/j.1525-1314.2005.00555.x

Rossi, M., Rolland, Y., Vidal, O., \& Cox, S. F. (2005). Geochemical variations and element transfer during shear-zone development and related episyenites at middle crust depths: Insights from the Mont Blanc granite (French-Italian Alps). Geological Society, London, Special Publications, 245, 373-396.

Rubatto, D., Chakraborty, S., \& Dasgupta, S. (2013). Timescales of crustal melting in the Higher Himalayan Crystallines (Sikkim, Eastern Himalaya) inferred from trace element-constrained monazite and zircon chronology. Contributions to Mineralogy and Petrology, 165(2), 349-372. 
Rubatto, D., Hermann, J., \& Buick, I. S. (2006). Temperature and bulk composition control on the growth of monazite and zircon during low-pressure anatexis (Mount Stafford, central Australia). Journal of Petrology, 47, 1973-1996.

Rumelhart, P. E., Yin, A., Cowgill, E., Butler, R., Zhang, Q., \& Wang, X.-F. (1999). Cenozoic vertical-axis rotation of the Altyn Tagh fault system. Geology, 27, 819-822.

Schmid, S. M., \& Casey, M. (1986). In B. E. Hobbs, \& H. C. Heard (Eds.), Complete fabric analysis of some commonly observed quartz c-axis patterns, Geophysical Monograph Series (pp. 263-286). Washington, D. C: American Geophysical Union.

Schneider, J., Corsini, M., Reverso-Peila, A., \& Lardeaux, J.-M. (2014). Thermal and mechanical evolution of an orogenic wedge during Variscan collision: An example in the Maures-Tanneron Massif (SE France). Geological Society, London, Special Publications, 405, 313-331. https://doi.org/10.1144/SP405.4

Law, R. D., Searle, M. P., \& Simpson, R. L. (2004). Strain, deformation temperatures and vorticity of flow at the top of the Greater Himalayan Slab, Everest Massif, Tibet. Journal of the Geological Society, 161, 305-320.

Shaw, J., \& Johnston, S. (2012). The Carpathian-Balkan bends: An oroclinal record of ongoing Arabian-Eurasian collision. In: Johnston, S., \& Rosenbaum, G. (Eds.), Oroclines. Journal of the Virtual Explorer, Electronic Edition, ISSN 1441-8142, 43, 4. https://doi.org/10.3809/ jvirtex.2012.00310

Simonetti, M. (2020), “Transpressive deformation in the Southern European Variscan Belt: New insights from the Aiguilles Rouges Massif (Western Alps) -DATASET-”, Mendeley Data, v1.

Simonetti, M., Carosi, R., \& Montomoli, C. (2017). Variscan shear deformation in the Argentera Massif: A field guide to the excursion in the Pontebernardo Valley (CN, Italy). Atti della Società Toscana di Scienze Naturali Residente in Pisa Memorie Serie a, 124, 151-169. https:// doi.org/10.2424/ASTSN.M.2017.25

Simonetti, M., Carosi, R., \& Montomoli, C. (2018). Shear deformation in the Southern European Variscan Belt: Kinematic of the flow and geochronological constraints. Young Researchers in Structural Geology and Tectonics 1-6 July 2018.

Simonetti, M., Carosi, R., Montomoli, C., Langone, A., D'addario, E., \& Mammoliti, E. (2018). Kinematic and geochronological constraints on shear deformation in the Ferriere-Mollières shear zone (Argentera-Mercantour Massif, Western Alps): Implications for the evolution of the Southern European Variscan Belt. International Journal of Earth Sciences, 107(6), 2163-2189. https://doi.org/10.1007/s00531-0181593-y

Simpson, C., \& de Paor, D. G. (1993). Strain and kinematic analysis in general shear zones. Journal of Structural Geology, 15, 1-20. https:// doi.org/10.1016/0191-8141(93)90075-L

Soliva, R., \& Benedicto, A. (2004). A linkage criterion for segmented normal faults. Journal of Structural Geology, 26, 2251-2267. https://doi. org/10.1016/j.jsg.2004.06.008

Stampfli, G. M., Borel, G. D., Marchant, R., \& Mosar, J. (2002). Western Alps geological constraints on western Tethyan reconstructions. Journal of the Virtual Explorer, 8, 77.

Stipp, M., Stunitz, H., Heilbronner, R., \& Schmid, S. M. (2002). The eastern Tonale fault zone: A "natural laboratory" for crystal plastic deformation of quartz over a temperature range from 250 to $700^{\circ} \mathrm{C}$. Journal of Structural Geology, 24, 1864-1884.

Tapponnier, P., \& Molnar, P. J. (1977). Active faulting and tectonics in China. Journal of Geophysical Research, 82, $2905-2930$.

Tapponnier, P., Peltzer, G., Le Dain, A. Y., Armijo, R., \& Cobbold, P. (1982). Propagating extrusion tectonics in Asia: New insights from simple experiments with plasticine. Geology, 10, 611-616.

Thomas, J. C., Claudel, M. E., Collombet, M., Tricart, P., Chauvin, A., \& Dumont, T. (1999). First paleomagnetic data from the sedimentary cover of the French penninic Alps: Evidence for Tertiary counterclockwise rotations in the western Alps. Earth and Planetary Science Letters, 171, 561-574.

Tikoff, B., \& Fossen, H. (1995). The limitations of three-dimensional kinematic vorticity analysis. Journal of Structural Geology, 17, $1771-1784$

Todesco, M., \& Vigliotti, L. (1993). When did Sardinia rotate? Statistical evaluation of the paleomagnetic data. Annali di Geofisica, 36, $119-134$.

Tollmann, A. (1982). Großraumiger variszischer Deckenbau im Moldanubikum und neue Gedanken zum Variszikum Europas. Geotektonische Forschungen, 64, 1-91.

Trudgill, B., \& Cartwright, J. (1994). Relay-ramp forms and normal-fault linkages, Canyonlands National Park, Utah. Geological Society of America Bulletin, 106, 1143-1157.

Tullis, J., Christie, J. M., \& Griggs, D. T. (1973). Microstructures and preferred orientations of experimentally deformed quartzites. Geological Society of America Bulletin, 84, 297-314.

Turco, E., Macchiavelli, C., Mazzoli, S., Schettino, A., \& Pierantoni, P. P. (2012). Kinematic evolution of Alpine Corsica in the framework of Mediterranean mountain belts. Tectonophysics, 579, 193-206. https://doi.org/10.1016/j.tecto.2012.05.010

van der Voo, R. (1993). Paleomagnetism of the Atlantic, Tethys and Iapetus oceans, (p. 411). Cambridge: Cambridge University Press.

Vanderhaeghe, O., \& Teyssier, C. (2001). Partial melting and flow of orogens. Tectonophysics, 342, 451-472.

Vollmer, F. W. (2015). EllipseFit 3.2 http://www.frederickvollmer.com/ellipsefit/

Von Raumer, J., Abrecht, J., Bussy, F., Lombardo, B., Menot, R.-P., \& Schaltegger, U. (1999). The Paleozoic metamorphic evolution of the Alpine external massifs. Schweizerische Mineralogische und Petrographische Mitteilungen, 79, 5-22.

Von Raumer, J., \& Bussy, F. (2004). Mont Blanc and Aiguilles Rouges geology of their polimetamorphic basement. Mémoires de Géologie (Lausanne), 42, 210.

Von Raumer, J., Dobmeier, C., \& Bussy, F. (2003). Variscan structures in the Aiguilles Rouges-Mont Blanc areas (External Massifs, Alps). Zentralblatt fur Geologie un Palaontologie, 1, 237-242.

Von Raumer, J. F. (1983). Die Metapelite von Emosson (Aiguilles- Rouges-Massiv) als Beispiel spätkaledonisch-frühvariszicher Metamorphose im Altkristallin des helvetischen Bereichs. Schweizerische Mineralogische und Petrographische Mitteilungen, 63, 421-455.

Von Raumer, J. F. (1984). The External Massifs, relics of Variscan basement in the Alps. Geologische Rundschau, 73(1), 1-31.

Von Raumer, J. F., \& Schwander, H. W. (1985). Garnet evolution in pre-Variscan pelitic rocks from the Lake Emosson area, Aiguilles Rouges Massif, Western Alps. Journal of Metamorphic Geology, 3, 467-479.

Wallis, S. R., Platt, J. P., \& Knott, S. D. (1993). Recognition of syn-convergence extension in accretionary wedges with examples from Calabrian arc and the Eastern Alps. American Journal of Science, 293, 463-495.

Walsh, J. J., Nicol, A., \& Childs, C. (2002). An alternative model for the growth of faults. Journal of Structural Geology, 24, 1669-1675.

Weinberg, R. F. (2016). Himalayan leucogranites and migmatites: Nature, timing and duration of anatexis. Journal of Metamorphic Geology, 34, 821-843. https://doi.org/10.1111/jmg.12204 
White, R. D. (1976). A Discussion on natural strain and geological structure - The effects of strain on the microstructures, fabrics, and deformation mechanisms in quartzites. Philosophical Transactions of the Royal Society of London. Series A, Mathematical and Physical Sciences, 283(1312), 69-86. https://doi.org/10.1098/rsta.1976.0070

Williams, M. L., Jercinovic, M. J., \& Hetherington, C. J. (2007). Microprobe monazite geochronology: Understanding geologic processes by integrating composition and chronology. Annual Review of Earth and Planetary Sciences, 35, 137-175. https://doi.org/10.1146/annurev. earth.35.031306.140228

Xypolias, P. (2010). Vorticity analysis in shear zones: A review of methods and applications. Journal of Structural Geology, 32, 2072-2092. https://doi.org/10.1016/j.jsg.2010.08.009

Xypolias, P., Chatzaras, V., Beane, R., \& Papadopoulou, S. (2013). Heterogeneous constrictional deformation in a ductile shear zone resulting from the transposition of a lineation-parallel fold. Journal of Structural Geology, 52, 44-59. https://doi.org/10.1016/j jsg.2013.05.001 